\title{
A Story Worth Remembering: \\ Literature's Role in Simone de Beauvoir's Philosophy
}

\begin{abstract}
By
Kayla Dold

A thesis submitted to the Faculty of Graduate and Postdoctoral Affairs in partial fulfillment of the requirements for the degree of

\author{
Masters of Arts \\ In \\ Political Science
}

\author{
Carleton University \\ Ottawa, Canada
}




\begin{abstract}
This thesis explores the relationship between philosophical content and literary form in Anglo-American political theory. The Anglo-American tradition is dominated by analytical approaches to philosophical objects that cannot adequately conceptualize ambiguous elements of lived experience. To do so, the study of political theory should include means of philosophizing that embrace ambiguity, such as Simone de Beauvoir's literature. This thesis takes Beauvoir's essay The Ethics of Ambiguity and novel All Men Are Mortal as case studies in how to theorize about ambiguous concepts. It applies a combined literary and phenomenological approach to reveal how her literary devices simulate our experience of ambiguity and freedom. It contributes to discourses on ethics and the relationship between form and content while serving as a model for research in political theory interested in alternatives to analytical approaches and the pursuit of experiential truths.
\end{abstract}




\section{Acknowledgements}

For Sophie: I will never find enough memes to describe how wonderful of a supervisor you are, but that won't stop me from trying.

For Kaitie, the Smith to my Hume. The Eliza to my Angelica — the best of wives and the best of women. My leave-in conditioner. My best friend: thank you for reading this.

And for Ben, just because.

Thank you to my committee members Dr. Marc Hanvelt and Dr. Sébastien Côté for their time and energy (and to my mock-defense 'committee members' for theirs).

This thesis was funded by the Social Sciences and Humanities Research Council of Canada and by Carleton University. 
Table of Contents

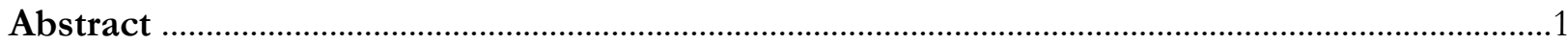

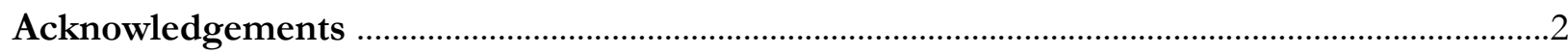

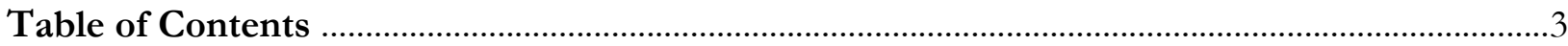

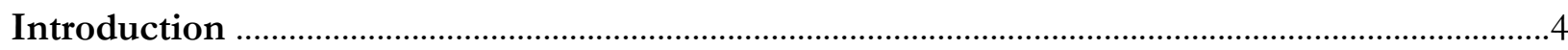

1. Literary Devices and Lived Experience ................................................................................... 12

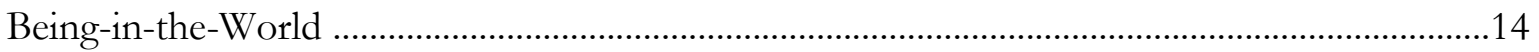

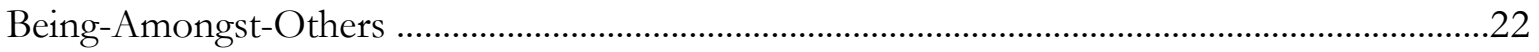

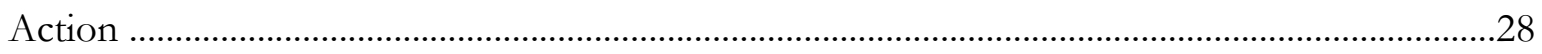

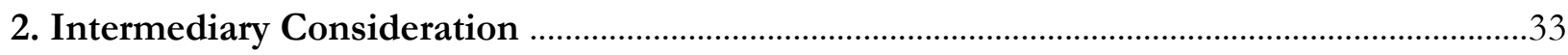

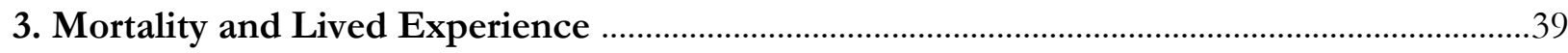

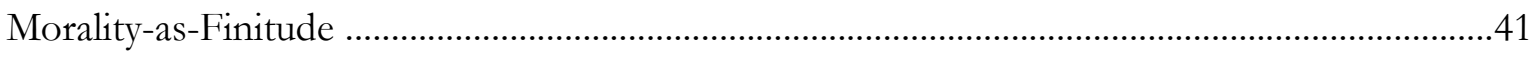

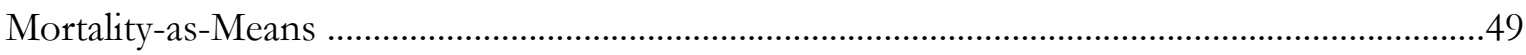

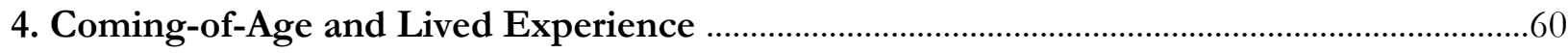

Regina: that strident monster of vanity and egoism ...............................................................62

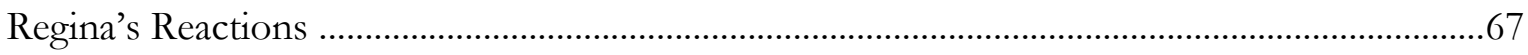

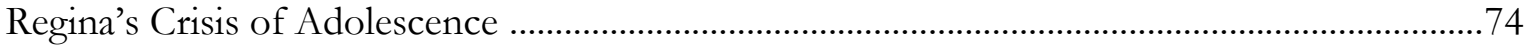

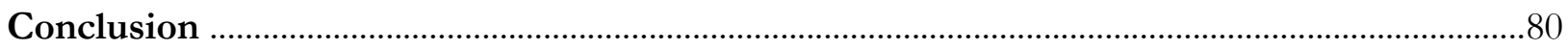

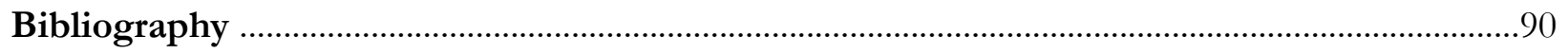




\section{Introduction}

Philosophy has often seen itself as a way of transcending the merely human, of giving the human being a new and more godlike set of activities and attachments. The alternative I explore sees it as a way of speaking humanly and being human. That suggestion will appeal only to those who actually want to be human, who see human life as it is, with its surprises and connections, its pains and sudden joys, a story worth remembering. ${ }^{1}$

\section{i.1 Ambiguity and Freedom}

In her long essay The Ethics of Ambiguity, French existentialist Simone de Beauvoir writes that "as long as there have been [people] and they have lived, they have all felt this tragic ambiguity of their condition, but as long as there have been philosophers, and they have thought, most of them have tried to mask it." "2 This describes how we commonly experience ambiguity: as an uncomfortable facet of everyday life that we, as political philosophers, try to solve with philosophical systems. Beauvoir's ethics takes ambiguity as its starting point; however, unlike her predecessors, she does not construct a philosophical system. This is because philosophical systems do not accommodate ambiguity. Beauvoir claims they mask, hide, or gloss over it.

Anglo-American philosophy rarely treats ambiguity as a serious philosophical object. ${ }^{3}$ It prioritizes analytical approaches and deductive reasoning that produce systems, clarity, and positive definitions. This is understandable, as we are pattern-finding creatures prone to translating chaos into digestible units. ${ }^{4}$ Ambiguity connotates the unknown, which makes its presence in philosophical systems problematic because it cannot be categorized. This does not mean that ambiguity is meaningless; rather, "to say that [something] is ambiguous is to assert that its meaning is never

\footnotetext{
${ }^{1}$ Martha Nussbaum, "Introduction," in Love's Knowledge: Essays on Philosophy and Literature (New York: Oxford University Press, 1990), 53.

2 Simone de Beauvoir, The Ethics of Ambiguity, trans. Bernard Frechtman (New York: Open Road Integrated Media Inc., 2019), 6.

3 According to Isaiah Berlin, this stems from a long history of trying and failing to do philosophy as empirical science. See Isaiah Berlin, "Does Political Theory Still Exist," "Historical Inevitability," and "The Concept of Scientific History" for a brief history of this failed philosophical alchemy.

${ }^{4}$ Margaret Simons, "Bergson's Influence on Beauvoir's Philosophical Methodology," in The Cambridge Companion to Simone de Beauvoir, ed. Claudia Card (Cambridge: Cambridge University Press, 2003), 109.
} 
fixed." ${ }^{5}$ The ambiguous is dynamic. It holds multiple meanings at once. Thus, to say that ambiguity is a part of the human experience is to say that the human experience can be unclear, unpredictable, and dynamic. It is to accept that not everything is predictable. This means that analytical philosophy might be incomplete no matter the scale or coherency of its systems and categories.

This does not mean that all philosophizing is pointless. Allowing for ambiguity provides an opportunity to philosophize about the human experience in ways that are as dynamic and creative as that experience. Facing the rigid systems of many Western philosophies, political theorist Isaiah Berlin argues we should re-conceptualize philosophy. ${ }^{6}$ He writes that "one of the surest hallmarks of a philosophical question... is that we are puzzled from the very outset, that there is no automatic technique, no universally recognized expertise, for dealing with such questions." ${ }^{7}$ Berlin argues that it is okay that our knowledge is never complete. We shift through experience and ideas for the best way to live, despite never agreeing on one. ${ }^{8}$ This opposes the Cartesian tradition of associating certainty and clarity with truth, and ambiguity with error. ${ }^{9}$ Like Berlin, Beauvoir reminds us of the relationship between ambiguity and truth. She calls us to "look the truth in the face... to assume our fundamental ambiguity." 10

Due to the spontaneity of individual choice, ambiguity is closely related to freedom. Being free does not mean that all human activity is ambiguous, but that our actions are neither pre-determined nor teleological. ${ }^{11}$ Beauvoir writes that "to exist genuinely is not to deny this spontaneous movement

\footnotetext{
${ }^{5}$ Beauvoir, The Ethics of Ambiguity, 139.

${ }^{6}$ Examples include Platonism, Thomism, Hobbes' new science, Kantianism, Hegelianism, Marxism, the analytic philosophies of Wittgenstein and Russel, even phenomenology like Heidegger's. Each system has unique internal rules and categories that are incompatible with others' and non-intuitive. In other words, while each has its purpose, it is divorced from everyday experience because they focus on abstract ideas or because their language is inaccessible.

${ }^{7}$ Isaiah Berlin, "Does Political Theory Still Exist?," in Isaiah Berlin: The Proper Study of Mankind, ed. Henry Hardy \& Roger Hausheer (London: Chatto \& Windus, 1997), 62-63.

8 Berlin, "Does Political Theory Still Exist?," 65.

9 Langer, "Beauvoir and Merleau-Ponty on Ambiguity," in Cambridge Companion to Simone de Beauvoir, ed. Claudia Card (Cambridge: Cambridge University Press, 2003), 89.

${ }^{10}$ Beauvoir, The Ethics of Ambiguity, 8.

11 Beauvoir, The Ethics of Ambiguity, 43.
} 
of my transcendence." ${ }^{12}$ Our capacity for free, spontaneous choice only contributes to the ambiguous condition of others. If my capacity for action is free, then my motivations are never completely known to you and vice versa. ${ }^{13}$ They are often, though not always, ambiguous. Living amongst others demonstrates two things: that we are free to make decisions and, therefore, there will always be things we cannot predict. In response, we should cultivate ways of philosophizing that 'look truth in the face' - ways that accept freedom and ambiguity as the everyday realities they are.

\section{i.2 Argument}

Looking the truth in the face implies we consider how things are prior to how things ought to be. If our task as political philosophers is to think about how we ought to live in community with others, we must start with how things are-with ambiguity's presence. This thesis builds on Simone de Beauvoir's work to model theorizing in a way that embraces the ambiguity, and associated freedom, of the human experience.

This thesis argues that Simone de Beauvoir's prose, which uses literary devices to deliver philosophical content, present freedom and ambiguity as embodied phenomena in the essay The Ethics of Ambiguity and novel All Men Are Mortal. This allows Beauvoir to flesh out an answer to one of the original questions of political theory: why we should form communities? The intimate relationship between Beauvoir's literary devices and philosophical content demonstrates how, by enacting our freedom amongst others free to enact theirs, we can live meaningful lives. It allows her to articulate an ethics consistent with our lived experience, suggesting how things ought to be based on our experience of how they are.

\footnotetext{
12 Beauvoir, The Ethics of Ambiguity, 13.
}

13 Beauvoir, The Ethics of Ambiguity, 6. 


\section{i.4 Methodology and Outline}

This thesis's approach to The Ethics of Ambiguity and All Men Are Mortal combines literary analysis with phenomenological hermeneutics to reveal the philosophical contributions of Beauvoir's literary devices. While literary analysis isolates examples of literary devices like tropes, images, and narration, phenomenological hermeneutics analyses their effect on the reader. This approach consists of asking four questions. The first is: what is literally happening? The answer to this question establishes the particular experience from which we intend to learn. It also situates us in Beauvoir's larger argument and narrative. The second question is: what literary devices is Beauvoir using? Since we are interested in ambiguity and associated conceptions of freedom, we focus on whether these devices simulate our experience of either. The third question is: how does this simulation relate to the larger political, philosophical, and existential traditions? This situates Beauvoir in a larger conversation and demonstrates her unique contributions. The final question is about action: based on our literal and figurative understanding of these texts, how is Beauvoir suggesting we act? The answer to this question fleshes out Beauvoir's ethical project. Together, these questions help us derive universal significance from the particulars of lived experience.

The following chapters likewise move from the particulars of literary expression to broader philosophical concepts. The first chapter argues that the literary devices of The Ethics of Ambiguity present freedom and ambiguity as embodied phenomena by simulating our experience. The second introduces the novel All Men Are Mortal while the third argues that, since freedom is embodied, All Men Are Mortal describes mortality as the fundamental ambiguity of human life: as both the end and the means of our freedom. While mortality establishes the upper limits of our action, it also serves as a common foundation upon which we can get together. The final chapter argues that paying particular attention to the development of All Men Are Mortals protagonist models Beauvoir's ethical imperative: to live a good life, we must get together and create meaning with others. The 
thesis concludes with final reflections on Beauvoir's literary devices and prompts for further research in political theory and Simone de Beauvoir studies.

Since this thesis models a means of doing political theory opposed to analytical approaches, its analysis of The Ethics of Ambiguity and All Men Are Mortal is situated in the Anglo-American tradition. This raises some contextual difficulties. For example, by engaging with the Anglo-American secondary literature, this thesis does not conduct detailed analysis of Beauvoir's original French linguistic context. ${ }^{14}$ Instead, it analyzes literary devices' effects on readers that are fairly consistent despite translation. For example, while the use of first-person plural narration is common in the French context but uncommon in the English, its effect on readers is consistent. Its incorporation into Anglo-American philosophy would lend our predominantly analytical tradition an intersubjectivity it currently lacks. Additionally, since Beauvoir is conventionally treated as a nonfiction writer in the Anglo-American tradition (largely due to our reception of The Second Sex and participation in the women's movement), focusing on her literary devices contributes to her AngloAmerican renaissance. ${ }^{15}$ It reveals facets of her ethics previously overlooked due to our oversight of her literary works despite Anglo-American influence on her own literary techniques. ${ }^{16}$

\footnotetext{
${ }^{14}$ All English translations are compared to the original French to distinguish direct translations from indirect. Only direct translations are analyzed devices in the first chapter.

15 Over the past 15 years, there has been an influx of Beauvoir's works published in English collections, including her student dairies and the Beauvoir Series collections (both edited by Sylvie le Bon de Beauvoir and Margaret A. Simons). There is also an interest in rescuing her from 'ancestor worship' in feminist studies by scholars like Sonia Kruks and Kate Kirkpatrick. For example, see Sonia Kruks, "Gender and subjectivity: Simone de Beauvoir and contemporary feminism," in Signs 18, no. 1 (1992) and Kate Kirkpatrick, "Past Her Prime? Simone de Beauvoir on Motherhood and Old Age," in Sophia 53 (2014).

${ }^{16}$ See Simone de Beauvoir, "My Experience as a Writer," "The Novel and the Theater," "an American Renaissance in France," "New Heroes for Old" in "The Useless Mouths" and Other Literary Writings, Memoirs of a Dutiful Daughter, and The Prime of Life.
} 


\section{i.3 Philosophy \& Literature}

This project requires we reconsider what is philosophically relevant. On one hand, Beauvoir does not consider herself a philosopher, but an essayist and author. ${ }^{17}$ On the other, if human experience is an object of philosophical inquiry, there is no reason to separate the author from the philosopher. Moral philosopher Martha Nussbaum claims that "literary form is not sperate from philosophical content." ${ }^{18}$ She argues that novels allow "concrete doings and imaginings take on... a universal significance." ${ }^{\prime 19}$ Beauvoir similarly argues that literature is capable of communicating across both personal and circumstantial difference. ${ }^{20}$ Particular stories can teach us about the common human experience.

This means that when we read Beauvoir's novel All Men Are Mortal, for example, we aim for truths about ambiguity that apply to the human experience generally. We are not interested in learning from All Men Are Mortal that a good way to antagonize your friends is to spread rumours about their fidelity — a particular lesson that might not apply in all cases. Instead, like Margaret Simons does in “Bergson's Influence on Beauvoir's Philosophical Methodology," we want to read with an eye towards broader demonstrations, like of characters' understandings of mortality and action. The particulars of these characters' lives contain opportunities to reflect on the common human experience. Philosophical inquiry does not have to monopolize such reflection.

If literature is philosophical, we can place Beauvoir's complete oeuvre on the shelf beside the philosophers she references, like G. W. F. Hegel and Jean-Paul Sartre. Our problem is that Beauvoir's work rarely makes this shelf. For example, North American research institutions use the

17 Simone de Beauvoir and Margaret A. Simons, “Simone de Beauvoir: An Interview,” in Feminist Studies 5, no. 2 (1979): 338.

18 Nussbaum, "Introduction", 3.

${ }^{19}$ Nussbaum, "Finely Aware and Richly Responsible," 148 \& 166; Beauvoir, The Ethics of Ambiguity, 145.

${ }^{20}$ Simone de Beauvoir, "What can Literature do?," in "The Useless Mouths" and other Literary Writings, ed. Margaret A. Simons and Marybeth Timmerman, trans. Marybeth Timmerman (Urbina: University of Illinois Press, 2011), 199. 
Library of Congress classification system. As it stands, someone looking to grasp Beauvoir's existentialism would have to visit five different sections including psychology, history, social science, and politics. ${ }^{21}$ This phenomenon is not restricted to the shelves. The excellent Beauvoir Series edited by Margaret A. Simons and Marybeth Timmerman brings together Beauvoir's essays, notes, and reviews but remains split into volumes of Literary Writings, Political Writings, Feminist Writings, and Philosophical Writings. This means someone interested in Beauvoir's literary theory might miss "Literature and Metaphysics," published in Philosophical Writings. Collections of secondary literature are likewise segregated. For example, The Cambridge Companion to Simone de Beawvoir is internally divided into philosophy, feminist theory, literature, and sociology and politics. ${ }^{22}$ While the book is part of The Cambridge Companions to Philosophy, suggesting all its contents are philosophically relevant, its internal divisions nudge readers to sections of interest. While such divisions can be useful, in Beauvoir's case, they risk misrepresenting her larger project.

Beauvoir's work is interdisciplinary, but by spreading her work across disciplines, we miss the opportunity to consider each text as part of a larger organic whole: Beauvoir's ethics. What we gain in ease of classification, we lose in philosophical richness. While Beauvoir is capable of treating ambiguity seriously, she does not get the credit she deserves since her ethical program is developed across multiple genres.

While Beauvoir's novels are sometimes invoked as illustrations of philosophical and political ideas, this rarely goes the other way around. Though Beauvoir describes The Ethics of Ambiguity as an

${ }^{21}$ For example: Pyrrhus et Cinéas. B2430.B3413P9, Philosophy, Psychology, Religion: Modern, by Region or Country; La Vieillesse. HV 1451.B41970, Social Pathology, Social Public Welfare, Criminology: Aged; Force of Circumstance. PQ2603.E362z51613, French, Italian, Spanish and Portuguese Literature: Modern, 1900-1960; America Day by Day. E169.B413, History of the Americas: General, United States; Simone de Beauvoir aujourd'bui: entretiens. HQ1154.S3214, Social Sciences: The Family, Marriage, Women, Women and Feminism.

${ }^{22}$ For example: Barbara Andrew's “Beauvoir's Place in Philosophical Thought;" Susan Beson's "Beauvoir on Feminism: Interview and Reflections;” Moira Gatens’s "Beauvoir and Biology: A Second Look;” Penelope Deutscher's "Beauvoir's Old Age." 
essay, ${ }^{23}$ it includes literary devices that are not conventionally associated with philosophical analysis in our contemporary Anglo-American context. For example, to explain how people are in the world yet separate from it, Beauvoir anthropomorphizes the natural world and invokes personal experience: "I should like this sky, this quiet water to think themselves within me, that it might be I whom they express in flesh and bone, and I remain at a distance... I cannot appropriate the snow field where I slide." ${ }^{24}$ By assigning the natural world a consciousness— 'think themselves within me' - Beauvoir emphasizes that the world is separate from us, though we exist in relationship to it. We can no more control the natural world than we can other consciousnesses. Her image of sliding down a hill simulates her point: anyone who has lost control on skis, or a toboggan, knows that our existence amongst the things of the world can be ambiguous and uncontrollable. Beauvoir's particular examples of ambiguity are rooted in experience and are brought to life with literary devices.

What connects the literary and philosophical is what Beauvoir calls 'doing metaphysics. ${ }^{, 25}$ For Beauvoir, metaphysics is a marriage between imagination and experience. Imagination is the key to effective literary devices like the anthropomorphication above. It develops images and comparisons that do not exist naturally in the world. ${ }^{26}$ Imagination is slightly removed from reality, but still connected to experience, because what we know or imagine about the world is grounded in our experience of it. $^{27}$ Beauvoir novels stem from her "lived and felt experience" yet give her the

23 Beauvoir, "Simone de Beauvoir: An Interview," 338.

${ }^{24}$ Beauvoir, The Ethics of Ambiguity, 11.

25 Simone de Beauvoir, "Literature and Metaphysics," in Simone de Beauvoir: Philosophical Writings, ed. Margaret A. Simons (Urbina: University of Illinois Press, 2004), 273.

${ }^{26}$ The role of imagination is to fill in what words cannot accurately express; Beauvoir writes that "words have to murder reality before they can hold it captive, and that the most important aspect of reality - its here and now presence - always alludes them." Simone de Beauvoir, The Prime of Life, trans. Peter Green (New York: Penguin Books, 1962), 40.

${ }^{27}$ Maurice Merleau-Ponty, "Metaphysical In Man," in Sense and Non-Sense, trans. \& ed. Hubert L. Dreyfus \& Patricia Allen Dreyfuss (Illinois: Northwestern University Press, 1964), 94. 
opportunity to explore philosophical ideas. ${ }^{28}$ The Ethics of Ambiguity demonstrates that doing metaphysics is not restricted to novels.

Therefore, this thesis contributes to Beauvoir scholarship by advocating for a new method of reading her work. Taking Beauvoir's literary devices seriously and treating her novels as autonomous contributors to philosophical discourse — rather than illustrations of ideas developed elsewherereveals Beauvoir's contribution to political theory and ethics. For Beauvoir, literary form and philosophical content are inseparable. A literary work, be it an essay or a novel, is open the reader's imagination, should the reader choose to engage. ${ }^{29}$ When reading, we seek to common truths about the human experience in particular cases born of the union between the writer's experience and the reader's interpretation. In order to appreciate Beauvoir as a philosopher, we need to take this practice seriously. Beauvoir's case proves that philosophical content is not restricted to systematic philosophy. Life is often ambiguous; thus, systemic approaches to the human experience can fall short of accurately describing the human experience. Since literary form allows us to consider the human experience in all its ambiguity, it can communicate experiential truths. If political theory is interested in the human experience, it should work with the literary towards a shared goal: to teach us how to live together as free agents in an ambiguous world.

28 Beauvoir, "Simone de Beauvoir: An Interview," 339.

${ }^{29}$ Marry Sirridge, "Philosophy in Beauvoir's Fiction," in The Cambridge Companion to Simone de Beauvoir, ed. Claudia Card (Cambridge: Cambridge University Press, 2003), 131. 


\section{Literary Devices and Lived Experience}

The individual is defined only by [their] relationship to the world and to other individuals [...] and [their] freedom can be achieved only through the freedom of others. ${ }^{30}$

\subsection{Introduction}

In a 1927 diary entry, Simone de Beauvoir writes 'I must... write 'essays on life' which would not be a novel, but philosophy, linking them together vaguely with a fiction." 31 Despite this early indication that Beauvoir was interested in writing essays using literary devices, scholars in our AngloAmerican tradition have focused on the philosophical content of her novels, rather than the literary quality of her essays. ${ }^{32}$ For example, Simons acknowledges that this diary entry reveals Beauvoir's “intention to write philosophy in literary form." ${ }^{33}$ However, instead of turning to her essays, Simons' article focuses on Beauvoir's novel She Came to Stay. By emphasizing the philosophical relevance of her novels, we risk missing the revelatory role Beauvoir's literary devices play in communicating the content of her essays. Other interpreters have approached Beauvoir's work with similar interdisciplinary attitudes, but Beauvoir's work remains classified as either philosophy or literature. ${ }^{34}$

Despite Beauvoir's early interest in writing essays that are both literary and philosophical, the literary devices of one of her best-known essays, The Ethics of Ambiguity (1947), has been overlooked. The Ethics of Ambiguity looks literary on the surface: it is riddled with references to novels and plays including Molière's Don Juan, Drieu la Rochelle's The Empty Suitcase, and Arthur Koestler's Darkness at Noon. However, acknowledging her literary references is not the same as acknowledging the

${ }^{30}$ Beauvoir, The Ethics of Ambiguity, 169.

${ }^{31}$ English translation quoted from Simons, "Bergson's Influence on Beauvoir's Philosophical Methodology," 110. Originally from Simone de Beauvoir, Cahiers de jeunesse: 1926-1930, ed. Sylvie le Bon de Beauvoir (Paris: Gallimard, 2008), 54-55.

${ }^{32}$ While the Anglo-American tradition primarily treats Beauvoir as a philosopher, rarely taking seriously the philosophical content of her literary devices or novels, it is common in the French tradition to treat her as a novelist. Regardless of tradition, both reinforce a division between what is literarily and what is philosophically relevant.

33 Simons, "Bergson's Influence on Beauvoir's Philosophical Methodology," 110.

34 See Anne Mudde, "Beauvoir's Metaphysical Novel: Literature, Philosophy, and Ambiguity," in Socrates and Dionysus: Philosophy and Art in Dialogue (Cambridge: Scholars Publishing, 2013), 192-203; Eleanore Holveck, Simone de Beauvoir's philosophy of lived experience: literature and metaphysics (Lanham: Rowman \& Littlefield, 2002). 
philosophical relevance of Beauvoir's literary devices. For example, Emily Anne Parker's essay "Singularity in Beauvoir's The Ethics of Ambiguity" explores Beauvoir's invocation of the absurd, arguing that it is the result of French novelist Albert Camus's influence. ${ }^{35}$ While Beauvoir describes a distinction between absurdity and ambiguity, attributing Beauvoir's imagery of the absurd to another author reinforces the division between philosopher and author, suggesting that literary devices and philosophical content are like oil and water: they do not mix.

The Ethics of Ambiguity, however, proves that literary devices and philosophical content are less like oil and water and more like gin and tonic; they do mix, and they mix rather well. In his essay on Beauvoir's novel She Came to Stay, French phenomenologist Maurice Merleau-Ponty argues in favour of writing that uses literary devices to express philosophical ideas. ${ }^{36}$ Merleau-Ponty writes that the ambiguities of literary expression allow the writer to address the human condition better than the metaphysician. ${ }^{37}$ This exegesis of The Ethics of Ambiguity follows Merleau-Ponty's approach to She Came to Stay by demonstrating how attention to literary devices can bring Beauvoir's philosophical concepts into a new light, thus treating the literary and philosophical as co-dependant. The literary character of The Ethics of Ambiguity makes the essay a unique contribution to existential discourse by describing ethical action based on our phenomenological experience of being-in-the-world. This chapter argues that the literary devices Simone de Beauvoir uses in The Ethics of Ambiguity allow her to conceptualize ambiguity and freedom as necessarily embodied by simulating this experience.

This exegesis focuses on three concepts: being-in-the-world, being-amongst-others, and action. It proceeds in three corresponding steps. The first examines how Beauvoir's use of narration and metaphor simulates our experience of being-in-the-world. The second demonstrates how

35 Emily Anne Parker, "Singularity in Beauvoir's The Ethics of Ambiguity," in The Southern Journal of Philosophy, 53 no. 1 (2015): 14.

${ }^{36}$ Maurice Merleau-Ponty, "Metaphysics and the Novel," in Sense and Non-Sense, trans. Hubert L. Dreyfus \& Patricia Allen Dreyfus (Illinois, Northwestern University Press, 1964), 27-28.

${ }^{37}$ Merleau-Ponty, "Metaphysics and the Novel," 28. 
conversation and stock characters simulate our experience of others. The third reveals how parables simulate ethical action.

\subsection{Being-in-the-World}

In this section, I argue that Beauvoir's use of first-person plural narration and "flesh and blood" (de chair et de sang) and "flesh and bone" (de chair et d'os) metaphors present ambiguity and freedom as part of our embodied experience of being in-the-world. On the one hand, first-person plural narration allows Beauvoir to simulate the phenomenological concept of experience (Erfahrung) by inviting us to adopt her first-person perspective as our own. On the other, metaphor allows Beauvoir to present freedom as embodied while simulating our experience of meaning making.

\subsubsection{First-person plural narration}

Beauvoir assumes we experience the world as separate from us despite our place in it. ${ }^{38}$ For example, where I stand in a room depends on the position of the furniture, but if I poke the couch, I cannot feel it. We have a similar experience of others. Though we live amongst others, we experience them as separate from us (if I poke you, I won't feel it). ${ }^{39}$ According to Beauvoir, feeling separate from the world we live in is a source of ambiguity, ${ }^{40}$ yet thinkers often neglect this lived experience. ${ }^{41}$ Beauvoir's use of first-person plural narration makes up for this oversight by presenting ambiguity as part of embodied experience. While first person plural narration was common in French philosophical writing when Beauvoir' wrote The Ethics of Ambiguity (and in fact is still common today), its banality in the French context does not occlude its performative function: to simulate lived experience, including ambiguity.

\footnotetext{
38 Beauvoir, The Ethics of Ambiguity, 5.

${ }^{39}$ Beauvoir, The Ethics of Ambiguity, 6.

${ }^{40}$ As Monika Langer points out, this means the truth of our experience includes ambiguity. Langer, "Beauvoir and Merleau-Ponty on Ambiguity," in The Cambridge Companion to Simone de Beauvoir, ed. Claudia Card (Cambridge: Cambridge University Press, 2003), 89.

${ }^{41}$ Beauvoir, The Ethics of Ambiguity, 6.
} 
Experiencing ambiguity is more informative than defining it as 'unclear or unknown,' which does not tell us anything. Ambiguity is best understood using a phenomenological approach, which describes being-in-the-world without pre-existing philosophical, cultural, historical, or scientific definitions. The objects of phenomenological study exist in the lifeworld (Lebenswelt), which Edmund Husserl first used to describe not only tangible things in the world but also social structures, language, ethical behaviour, and consciousness. These are approached from a first-person perspective. Phenomenology is therefore a descriptive study, unlike third-person argumentative studies, which tend to dominate philosophical and scientific productions. ${ }^{42}$

Phenomenology is concerned with uncovering our immediate experience of the lifeworld. Reflecting on her young adulthood during the 1930s, Beauvoir wrote "the novelty and richness of phenomenology filled me with enthusiasm; I felt I had never come so close to the real truth." ${ }^{43}$ Beauvoir discusses phenomenology in The Ethics of Ambiguity as well. In her view, both phenomenology and existentialism refuse to describe the lifeworld according to customs, ideas, or traditions sedimented in it, but do not ignore the influence those have on action either. ${ }^{44}$ Being-inthe-world means that "facticity, historicity, and sociality underdetermine our being," ${ }^{45}$ though do not necessarily determine it. The structures and customs of the lifeworld do not completely determine who we are, though we understand ourselves in relation to them. This does not mean that we adopt pre-existing categories to define being-in-the-world but that we recognize that anthropogenic categories influence our self-understanding.

Acknowledging our experience of being-in-the-world is therefore a necessary condition of understanding how we should act. Beauvoir's first-person plural narration, invites us to adopt her

42 Taylor Carman, "Forward," to Phenomenology of Perception (Axon: Routledge, 2014), viii.

${ }^{43}$ Beauvoir, The Prime of Life, 201.

44 Beauvoir, The Ethics of Ambiguity, 13.

${ }^{45}$ Paul Fairfield, Moral Selfhood and the Liberal Tradition: the Politics of Individuality (Toronto, University of Toronto Press, 2000), 145. 
perspective when reading, simulating an experience of being-in-the-world. Canadian cognitive scientist Keith Oatley develops the concept of simulation in his research on the social elements of fiction. Oatley provides a neurological description of how this simulation works. For example, when we read "Simone poured a gin and tonic," the same parts of our brains light up as when we physically pour a gin and tonic. ${ }^{46}$ Reading therefore constitutes a virtual reality.

Oatley's conception of simulation aligns with Beauvoir and Merleau-Ponty's phenomenological descriptions of how reading invokes being-in-the-world. Beauvoir's use of firstperson plural narration allows her to disclose her perspective of the lifeworld to us in a way that allows us to try on her perspective for ourselves. When we adopt another's perspective, their experience mingles with our own, as if we view the world through a lens coloured with both our previous experience of the world, of say, what it is like to pour a drink, and how the writer describes their experience of drinking. When reading, our experience passes through Beauvoir's like light through a prism.

By using first-person plural narration, Beauvoir simplifies this process. The words 'we,' 'our,' and 'us,' present a collective as a single entity; first-person plural pronouns are inherently intersubjective. For example, when describing the steps of her discussion, Beauvoir writes, "we think that the meaning [nous pensons que le sens]," "it appears evident to us [il nous apparaît evident que]," "it appears to us [il nous apparaît]," "but if we consider [mais si nous considérons]," "it seems like the 'Hegelian' notion of displacement which we relied on a little while ago is now turning against us [il semble que se retourne alors contre nous cette notion de 'déplacement' bégélien sur laquelle nous nous appuyions tout à l'heur]," "we have said [nous avons dit]," "we, too describe [nous définisson nous aussi]," and "we shall limit ourselves to describing [nous nous bornerons à déscrire]." ${ }^{47}$ Beauvoir's use of second-person

\footnotetext{
${ }^{46}$ Keith Oatley, Such Stuff as Dreams: The Psychology of Fiction (West Sussex: Wiley Blackwell, 2012), 19-21.

${ }^{47}$ Beauvoir, The Ethics of Ambiguity, 19, 23, 24, 34, 35. Original French from Simone de Beauvoir Pour une morale de l'ambiguity, Les essais XXVI (Paris: Gallimard, 1947), Kobo e-book edition.
} 
narration is like the royal we. When a sovereign refers to themselves as 'we,' they imply a subjectivity that symbolically encompasses their subjects. This is an essential feature of Merleau-Ponty's phenomenology at work in Beauvoir's text. In Beauvoir's case, first-person plural pronouns symbolize separate subjects meeting in an intersubjective space and taking on alternative perspectives. We join Beauvoir in her argumentation. ${ }^{48}$

The process of adopting another's perspective is integral to meaning making. Beauvoir writes that literary writing "is an activity carried out by [people] for [people], in order to disclose the world to them." 49 Similarly, Merleau-Ponty writes that creative language opens us to new perspectives and therefore creates meaning. ${ }^{50}$ Each unique situation in which we find ourselves is open to others because we can describe it. ${ }^{51}$ In the case of literary or creative writing, the writer describes their understanding of the world, which the reader incorporates into their own experience by reading. ${ }^{52}$ As Beauvoir says, reading is a "swirling of individual experiences that envelop each other while remaining separate." ${ }^{53}$ Like a soft-serve ice cream cone that has chocolate and vanilla swirled together, the subjectivities of the writer and reader meet each other in an intersubjective space where meaning making is possible.

When reading, we suspend our subjectivity in favour of the intersubjective experience of reading itself. Beauvoir acknowledges this connection by describing The Ethics of Ambiguity as a quest undertaken alongside her readers: "indeed, we are coming to the real situation of the problem [...]

\footnotetext{
${ }^{48}$ In comparison, Beauvoir transitions to first person singular or third person when giving examples or making generalizations; for example, the transition of time: "If I leave behind an act which I have accomplished [Si j'abandonne derrière moi une acte que j'ai accompli];" or human experience: "He is still a part of this world of which he is a consciousness [ce monde dont il est conscience, il en fait encore partie]," Beauvoir, The Ethics of Ambiguity, 27 \& 5. Original French from Beauvoir, Pour une morale de l'ambiguity, Kobo e-Book edition.

49 Beauvoir, "What Can Literature Do?," 197.

50 Maurice Merleau-Ponty, "Indirect Language and the Voices of Silence," in Signs, trans. Richard McCleary (Illinois: Northwestern University Press: 1964), 44-45.

51 Beauvoir, "What Can Literature Do?," 199.

52 Beauvoir, "What Can Literature Do?," 199.

${ }^{53}$ Beauvoir, "What Can Literature Do?," 199.
} 
Before undertaking the quest for a solution, it is interesting to note that the notion of situation and the recognition of separation which it implies." ${ }^{54}$ While acknowledging the intersubjectivity of her writing, Beauvoir also acknowledges separation, which her writing does not completely dissolve. This emphasizes how our experience of being-in-the-world is one of being amongst, yet separate from, things and others. There is a parallel between our experience of reading and our experience of others: both require us to navigate the experience of intersubjectivity as separate subjects.

Separation leads Beauvoir to address solipsism (a conception of the self as the only autonomous agent in the world). Beauvoir's ethics of ambiguity maintains that individuals are the source of meaning, implying that meaning is subject to the whims and fancies of isolated individuals. This is not the case; Beauvoir writes that individuals create and affirm meaning in community with each other. ${ }^{55}$ This is consistent with her theory of literary writing, which maintains that meaning making occurs in the intersubjective space reading establishes. ${ }^{56}$ Thus, an ethics of ambiguity does not assume individuality and community are mutually exclusive categories. Beauvoir writes that we are "nothing more than an individual in the collectivity on which [we] depend." ${ }^{57}$ Being an individual in the collectivity upon which we depend does not erase separation but provides opportunities to disclose our experience to others and thereby establish meaning.

Throughout The Ethics of Ambiguity, first-person plural narration encourages readers to adopt Beauvoir's perspective. Beauvoir tells us that separation is a condition of being-in-the-world, a source of ambiguity, and that meaning making is the result of assuming other perspectives, as we do when we read The Ethics of Ambiguity. Being-in-the-world is not only the source of both ambiguity

\footnotetext{
${ }^{54}$ Beauvoir, The Ethics of Ambiguity, 17.

55 Beauvoir, The Ethics of Ambiguity, 17.

${ }^{56}$ Beauvoir, "Literature and Metaphysics," 276.

${ }^{57}$ Beauvoir, The Ethics of Ambiguity, 6.
} 
and meaning, but the condition under which we must enact our freedom. This brings us to Beauvoir's metaphor for freedom.

\subsubsection{Metaphor}

Beauvoir's metaphor for freedom consists of flesh, blood, and/or bone. ${ }^{58}$ Beauvoir shifts over the course of the text from using flesh, blood, and bone literally to figuratively. This means that when we arrive at her figurative use, we are equipped to interpret the metaphor philosophically. This section argues that this metaphor describes freedom as embodied; it must have a physical and temporal presence. It must be translated into action by our being-in-the-world.

Our exposure to the phrase 'flesh and blood' or 'flesh and bone' over the course of The Ethics of Ambiguity guides our interpretation. Merleau-Ponty describes this process of shifting from literal to figurative meaning in his essay "On the Phenomenology of Language." He writes that the meaning of a phrase becomes sedimented in language with use over time. ${ }^{59}$ In other words, with use, our language becomes part of the lifeworld. When we communicate with words, we draw from preestablished meanings and re-arrange them so they express something specific or new. Each use of words, new and creative at first, becomes part of our language, which we build upon. In Beauvoir's case, the literal meaning of flesh and blood or bone are steppingstones towards figurative meaning, a process neglected by previous interpreters.

Beauvoir primes us for her figurative use of flesh and blood or bone by using these words literally. The first occurrence is in reference to herself. She writes: "I should like this sky, this quiet water to think themselves within me, that it might be I whom they express in flesh and bone [en chair et en os], and I remain at a distance." ${ }^{60}$ In this quotation, Beauvoir describes the experience of being-

58 The use of en chair et en os in French is similar to the English use of "in the flesh." For example, last year, I saw Shawn Mendes in the flesh. In both cases, it means "in real life."

${ }^{59}$ Maurice Merleau-Ponty, "On the Phenomenology of Language," in Signs, trans. Richard McCleary (Illinois: Northwestern University Press, 1964), 92.

${ }^{60}$ Beauvoir, The Ethics of Ambiguity, 11; Original French from Pour une morale de l'ambiguity, Kobo e-book edition. 
in-the-world yet separate from the world. Her use of flesh and bone refers to her own body: without her body, Beauvoir would be unable to perceive the world around her. The separation between herself and her surroundings allows Beauvoir to experience them from a first-person perspective.

Beauvoir's second use of flesh and bone also refers to experiencing the world. She writes that “just as phenomenological reduction prevents the errors of dogmatism by suspending all affirmation concerning the mode of reality of the external world, whose flesh and bone [de chair et d'os] presence the reduction does not, however, contest, so existentialist conversion does not suppress my instincts, desires, plans, and passions. ${ }^{\circ 1}$ Beauvoir once again uses flesh and bone to refer to physical reality, but unlike the previous passage, she does not refer to her body. In this passage, we understand flesh and blood, not in reference to body parts, but in reference to other things in the world. This use of flesh and bone establishes it as a referent, not only of bodies, but of all perceptible phenomena. The repeated use of the metaphor sediments flesh and bone in our language in reference to physicality.

Beauvoir's next use of flesh and bone is juxtaposed with something non-physical. In her discussion of Marxist revolutionary action, she writes that "if one pretends to distinguish the real proletariat from a treacherous proletariat, or a misguided or unconscious one, then it is no longer a flesh and blood [de chair et d'os] proletariat that one is dealing with, but the idea of the proletariat, one of those ideas that Marx ridiculed." ${ }^{62}$ Beauvoir's juxtaposition of physical flesh and blood with an imaginary person exposes us to the possibility of using a referent of physical phenomenon figurately. Beauvoir transitions to figurative use by introducing comparisons between a physical and nonphysical thing: the idea of a proletariat with an actual proletariat.

Building off our understanding of flesh and bone as referring to physical embodiment, Beauvoir uses flesh and blood figuratively to describe freedom. She writes that,

${ }^{61}$ Beauvoir, The Ethics of Ambiguity, 13; Beauvoir Pour une morale de l'ambiguity, Kobo e-Book.

${ }^{62}$ Beauvoir, The Ethics of Ambiguity, 20; Beauvoir Pour une morale de l'ambiguity, Kobo e-Book. 
the past will be integrated, and freedom will be confirmed in a renunciation of this kind. It will be lived in both heartbreak and joy. In heartbreak, because the project is then robbed of its particularity-it sacrifices its flesh and blood [sa chair et son sang]. But in joy, since at the moment one releases [their] hold, [they] again finds [their] hands free and ready to stretch out toward a new future. ${ }^{63}$

In this passage, Beauvoir describes the passage of time. Over time, our actions are integrated into our understanding of ourselves but cease to exist as observable phenomena. As time passes, freedom takes on a concrete physical reality in the form of our actions-ourselves. Once the action is complete, it no longer exists as part of our physical presence in the world. This leaves us free to do other things. Freedom, as an idea, has no physical presence in the world until it is enacted. Freedom exists insofar as we transform it into a physical phenomenon by acting.

When we act, we are our freedom; it takes on our flesh and blood presence and then passes into the past, leaving us free to act again, similarly to how language use supports new meaning over time. In reference to the past, Beauvoir writes that "the past as something not surpassed, in its flesh and blood [de chair et de sang] presence, has completely vanished." ${ }^{\prime 64}$ Actions that are not used as steppingstones towards, or inspiration for, other actions cease to exist. The past is inaccessible insofar as we cannot perceive it directly, but if we surpass our actions—in other worlds, let them inspire other actions — they are not completely gone. By using flesh and blood to describe enacted action, Beauvoir suggests that freedom can exist as long as we have a physical presence in the world. This opposes the tradition of thinking about philosophical objects in an idealized vacuum; Beauvoir's insistence on embodiment makes freedom relevant to us as actors.

This metaphor also simulates the process of language sedimentation, whereby the literal meaning of the phrase is established between us and Beauvoir, allowing Beauvoir build off literal meaning to explain a new idea. Beauvoir's conception of freedom becomes part of our language that

${ }^{63}$ Beauvoir, The Ethics of Ambiguity, 30; Beauvoir Pour une morale de l'ambiguity, Kobo e-Book.

${ }^{64}$ Beauvoir, The Ethics of Ambiguity, 98; Beauvoir Pour une morale de l'ambiguity, Kobo e-Book. 
we can build off of in turn. For example, in her essay "Literature and Metaphysics," Beauvoir writes that "in the real world, the meaning of an object is not a concept graspable by pure understanding. Its meaning is the object as it is disclosed to us in the overall relation we sustain with it, and which is action, emotion, and feeling. We ask novelists to evoke this flesh-and-blood presence [présence de chair et d'os] whose complexity and singular and infinite richness exceed any subjective interpretation." ${ }^{65}$ Our analysis of Beauvoir's use of flesh and blood or bone in The Ethics of Ambiguity helps us understand her meaning in this passage. In this case, Beauvoir describes the novelist's task as simulating our experience of being-in-the-world and amongst-others. By describing freedom as embodied, Beauvoir reminds her readers that separation limits our capacity for understanding. Our capacity for meaning making helps us navigate the ambiguity caused by separation; however, it is not foolproof. The next step is to see how Beauvoir's literary devices simulate this experience.

\subsection{Being-Amongst-Others}

Beauvoir's special attention to language is common amongst thinkers interested in describing the lifeworld. Merleau-Ponty wrote that "the reason why the return to the Lebenswelt [lifeworld] (and particularly the return from objectified language to speech) is considered absolutely necessary is that philosophy must reflect upon the object's mode of presence to the subject." ${ }^{\text {66 }}$ According to MerleauPonty, language use is particularly important for understanding personal relationships. Speaking, listening, reading, and writing reveal the presence of others. Such linguistic activities demonstrate our subjectivity—we show others that we have a unique, first-person experience of the lifeworld as they do. There are two ways that Beauvoir uses language to simulate our experience of others in The Ethics of Ambiguity: conversation and stock characters.

${ }^{65}$ In this case, the translator chose 'blood' instead of the literal translation of bone. Beauvoir, "Literature and Metaphysics," 270; Original French from Simone de Beauvoir, "Littérature et métaphysique," in Les Temps Modernes 1 , no. 7 (1946): 1154.

${ }^{66}$ Merleau-Ponty, “On the Phenomenology of Language," 92. 


\subsubsection{Conversation}

Beauvoir's use of conversational prose throughout The Ethics of Ambignity simulates the experience of speech as Merleau-Ponty describes it in "Indirect Language and the Voices of Silence." Therein, he suggests that meaning is established by the use of language amongst others. ${ }^{67}$ Thus, meaning does not exist independently from conversation. Beauvoir similarly writes that when "language is heard, it awakens an echo in the hearts of those to whom it is addressed." ${ }^{68}$ Like Merleau-Ponty, Beauvoir acknowledges that conversation forces us to acknowledge others.

Beauvoir writes conversation prose throughout The Ethics of Ambiguity, simulating the experience of separation. For example, Beauvoir addresses the accusation that existentialism is solipsistic. As we saw above, Beauvoir dismisses this claim by arguing that individuals create meaning in community with each other, not in isolation. ${ }^{69}$ In this way, existentialism builds on the works of Kant, Fitchte, and Hegel, who posit that the essence of right action and the will of individuals "are absolutely identical." 70 Beauvoir continues to say that the lifeworld exists as a result of our activities and interaction with others. ${ }^{71}$ Beauvoir then anticipates our reaction: "Some will answer, 'All well and good. But Kant escapes solipsism because for him genuine reality is the human person insofar as it transcends its empirical embodiment and chooses to be universal.",72 By explicitly invoking an imaginary interlocuter, Beauvoir forcers her readers to confront the opinions and arguments of others.

\footnotetext{
${ }^{67}$ Merleau-Ponty, "Indirect Language and the Voices of Silence," 42.

68 Beauvoir, The Ethics of Ambiguity, 21.

${ }^{69}$ Beauvoir, The Ethics of Ambiguity, 16.

${ }^{70}$ Beauvoir, The Ethics of Ambiguity, 16.

${ }^{71}$ Beauvoir, The Ethics of Ambiguity, 16.

${ }^{72}$ Beauvoir, The Ethics of Ambiguity, 16.
} 
This conversational form has a long history in Western philosophy, starting with Plato's

dialogues. By re-envisioning this passage as a dialogue, the conversational element becomes clearer:

Beauvoir: People give meaning to the world by acting, by completing projects and setting up goals for themselves, by choosing what is important to them and working towards it.

German Idealist: So, meaning depends on what individuals want. That sounds self-centered. You say existentialism builds off Kant and Hegel, but Kant avoids this problem by arguing that individuals identify with universal themes and meaning. Hegel argues that the particular moment is only part of a larger totality, a universal whole.

Beauvoir: Thinking of ourselves as small parts of a whole does not correspond with our experience. Existentialists are like Kant and Hegel insofar as we take individuals as separate beings, but we think individuals can get together to create meaning without sacrificing their subjectivity. Building off of Kant and Hegel does not mean agreeing with them.

Another example of Beauvoir's conversational prose is embedded in her discussion of

liberation. Beauvoir argues that ethical political action must hold freedom as its ultimate end.

Beauvoir writes that "what [Flora Tristan] wanted for the workers had first to be wanted without

them. 'But what right does one have to want something for others?' asks the conservative, who

meanwhile regards the workingman or the native as a 'grown up child' and who does not hesitate to

dispose of the child's will." ${ }^{\text {73 }}$ Again, Beauvoir' prose invites us to re-envision this conversation as a dialogue:

Beauvoir: When campaigning for worker's rights, $19^{\text {th }}$ century socialists made the mistake of not explaining why freedom is important to members of the working class.

Conservative: It sounds like socialists impose their values onto those they want to help. Isn't that another form of oppression?

Beawvoir: Explaining the meaning of freedom is important because it can inspire others to desire freedom for themselves. The idea is to empower, not to make choices for others. Your sensitivity to oppression is funny considering you often dismiss others when their goals to do not align with yours.

In both cases, Beauvoir explains her understanding of freedom by simulating a conversation with a hypothetical critic. Unlike conventional straw-man arguments, her hypothetical critics are explicitly

\footnotetext{
${ }^{73}$ Beauvoir, The Ethics of Ambiguity, 92.
} 
invoked, making it easier to imagine them in flesh and blood. Beauvoir's prose forces us to confront others and to imagine conversing with them, the process through which understanding, or meaning making, is achieved.

By writing conversational prose, Beauvoir simulates the process of confronting another and engaging them in meaning making. Conversation is completely engrossing; in conversation, "self and activity become one." ${ }^{\prime 4}$ This simulates the intersubjectivity of the lifeworld, emphasizing the alternative positions of others. It is interesting, however, that Beauvoir does not complete these conversations. At no point do her imaginary interlocuters agree with her conception of freedom, suggesting that ambiguity is not always overcome by conversation. Meaning is not always agreed upon despite our engagement in the process.

\subsubsection{Stock Characters}

The fact that none of her conversations come to formal conclusions indicates that Beauvoir does not think language can completely overcome ambiguity. Beauvoir's imaginary interlocuters are symbolic of particular ethical attitudes, and as such, lack the capacity to integrate other's perspectives into their own. They are stock characters, which lack the capacity for meaning making because they were created with a specific attitude in mind. Beauvoir uses ten stock characters throughout The Ethics of Ambiguity to simulate the experience of ambiguity in communication. ${ }^{75}$ In her book The Bonds of Freedom: Simone de Beauvoir's Existentialist Ethics, Kristina Arp describes these characters as personality types and attitudes. ${ }^{76}$ While each stock character presents an attitude, imagining them as a character, rather than an abstracted way of being, simulates the ambiguity of meeting others in the lifeworld.

\footnotetext{
74 Oatley, The Psychology of Fiction, 56.

75 The child, the sub-person, the serious person, the nihilist, the adventurer, the passionate person, the critic, the artist, the tourist, and the aesthetic. Beauvoir, The Ethics of Ambiguity, 37, 45, 50, 56, 62, 68, 71, 74, 80.

${ }^{76}$ Kristina Arp, The Bonds of Freedom: Simone de Beauvoir's Existentialist Ethics (Chicago: Open Court, 2001$), 33$.
} 
Beauvoir's first character is the child, who arrives in a world they did not help build. ${ }^{77}$ From the child's perspective, things in the world, and their meaning, are given. As the child grows up, they realize meaning is not factual but subjective. ${ }^{78}$ This presents the child with a choice. They can create and adopt meaning, understanding that meaning is their responsibility, or they can continue to behave as though meaning is given by something other than themselves. If the child does not assume their responsibility for meaning, they become a serious person.

The serious person, like the child, considers meaning to be ready-made. However, unlike the child, the serious person knows better. Beauvoir writes that "there is the serious from the moment that freedom denies itself to the advantage of ends which one claims are absolute."79 Over time, the serious person may realize value is not inherent in things. Confronted with the supposed meaninglessness of things, the serious person faces a choice: to enact their freedom and create meaning for themselves or to develop a nihilistic attitude. ${ }^{80}$ The nihilist, "conscious of being unable to be anything, decides to be nothing." ${ }^{81}$ Beauvoir writes that a "nihilist is right in thinking that the world possesses no justification and that he himself is nothing. But he forgets that it is up to him to justify the world and to make himself exist validly." 82 This character rejects their responsibility to enact their freedom and create meaning for themselves. ${ }^{83}$

The child, the serious person, and the nihilist are three of the stock characters that Beauvoir uses in The Ethics of Ambiguity to expose her readers to others, their possible ethical attitudes, and the potential for ambiguity in our relations with them. Stock characters are particularly suited to simulate the ambiguity of being-amongst-others because their inner thoughts are inaccessible. Their

\footnotetext{
77 Beauvoir, The Ethics of Ambiguity, 37.

78 Beauvoir, The Ethics of Ambiguity, 39.

${ }^{79}$ Beauvoir, The Ethics of Ambiguity, 50.

${ }^{80}$ Beauvoir, The Ethics of Ambiguity, 56.

${ }^{81}$ Beauvoir, The Ethics of Ambiguity, 56.

82 Beauvoir, The Ethics of Ambiguity, 61.

${ }^{83}$ Beauvoir, The Ethics of Ambiguity, 57.
} 
perspectives remain mysterious, unlike Beauvoir herself or the characters we often read in contemporary novels.

Beauvoir's characters find their place roughly halfway along the evolution of Western character. Some of the earliest characters are archetypal heroes, who we often find in classical and medieval literature. Examples include Achilles, Aeneas, Sir Galahad, and Pryderi fab Pwyll. ${ }^{84}$ These characters anthropomorphize virtues like honour, charity, or purity. Beauvoir's stock characters are similar to archetypal heroes in the sense that they also represent ethical attitudes; however, Beauvoir's characters develop their attitudes in response to being-in-the-world and amongst-others, while archetypal heroes are relatively unmalleable. For example, a serious person can become a nihilist as a result of their choices, while Sir Galahad of Le Morte D'Arthur is morally pure from the start to finish, despite the plot's events.

Since Beauvoir's characters develop their ethical attitudes in reaction to being-in-the-world, they have more in common with the characters of Renaissance humanism than archetypal heroes. Renaissance humanist characters develop their traits in response to action. For example, the characters in Dante Alighieri's Inferno sit in a specific circle of hell as a result of their life choices. These characters also represent different ethical attitudes like gluttony or greed, but unlike archetypal heroes, they do so as a result of their experience of being-in-the-world. Similarly, the child, the serious person, and the nihilist all represent certain attitudes as a result of choices we, as readers, rarely see them make. Beauvoir's characters are not described amidst the complexities of plot. Like characters in the Inferno, they remain slightly abstracted from being-in-the-world and their decisionmaking process remains a mystery to us.

\footnotetext{
${ }^{84}$ Achilles features in the ancient Greek Homeric poems The Illiad. Aeneas features in Vergil's Roman epic The Aenead. Sir Galahad features in Medieval King Arthur legends like Le Morte D'Arthur and Pryderi fab Pwyll features in The Mabinogian, a collection of Medieval Welsh legends.
} 
For example, a serious person "who has raised the highway to the stature of an idol will have no scruple about assuring its construction at the price of a great number of lives of the natives; for, what value has the life of a native who is incompetent, lazy, and clumsy when it comes to building highways?" 85 In this case, we do not see the serious person wrestling with the complexities of moral dilemma - weighing their options and considering how the consequences of their actions could impact others. They have 'no scruple.' Yet as a character, we assume they made a decision because our experience suggests that decisions typically precede actions. Stock characters seem two dimensional to us because we are accustomed to contemporary characterization, which includes a description of the character's motivations, desires, inner scruples, and emotions. However, the lack of access to the stock characters' mental processes simulates our experience of being-amongstothers because the inner recesses of others are often inaccessible to us.

\subsection{Action}

The literary devices Beauvoir employs throughout The Ethics of Ambiguity present ambiguity and freedom as necessarily embodied by simulating our experience of being-in-the-world and beingamongst-others. Beauvoir's final device, parable, shows us what ethical action looks like in this world. Parables have short plots, allowing us to make sense of and evaluate action. The role plot plays in articulating Beauvoir's conception of embodied ambiguity and freedom remains understudied in her essays, nor is it a central topic in studies of her novels. ${ }^{86}$ In the case of Beauvoir's ethic of ambiguity, it is necessary to explore plot because freedom must be enacted.

Beauvoir's ethics has one imperative: to try to act in ways that respect others' capacity for freedom. Ethical action will change depending on the circumstances; "there must be a trial and

\footnotetext{
85 Beauvoir, The Ethics of Ambiguity, 53.

${ }^{86}$ For example, see Margaret A. Simons, "From Murder to Morality: The Development of Beauvoir's Ethics," in International Studies in Philosophy, vol. 31, no. 1, 1999, 1-20; Sirridge, "Philosophy in Beauvoir's Fiction," 129-148.
} 
decision in each case." ${ }^{87}$ Beauvoir simulates this process through a series of parables that guide us through her ethical approach. Parables — which include character, setting, and plot—show how Beauvoir envisions her ethics in action.

\subsubsection{Parables}

Parables, like fables and fairy tales, often have an ethical message; however, unlike fables or fairy tales, parables have an interpretive element. ${ }^{88}$ Fables and fairy tales tend to bully their readers into specific interpretations. ${ }^{89}$ For example, don't talk to strangers (Little Red Riding Hood) or don't be lazy (The Three Little Pigs). For this reason, Beauvoir considers them oppressive. ${ }^{90}$ Beauvoir also uses historical examples to simulate moral behaviour, but they are likewise limited. Since historical examples have played out in time, our interpretations are constrained by their consequences. Parables have not played out in real time; their interpretation is open to our imaginations. The interpreter is therefore largely responsible for determining the parable's meaning. In this sense, Beauvoir's use of parable is consistent with her ethics: she writes so that her conception of being-inthe-world is disclosed to us but not so that she denies our interpretation. ${ }^{91}$ Like first-person plural narration, the parable invites us to join Beauvoir in an imaginary intersubjective to create meaning together.

This does not mean that our interpretation is unlimited. What comes before and after the parable limits its interpretation. ${ }^{92}$ Likewise, what Beauvoir says throughout The Ethics of Ambiguity about ambiguity and freedom guides our interpretations of her parables. Beauvoir's constraints on

${ }^{87}$ Beauvoir, The Ethics of Ambiguity, 145.

${ }^{88}$ Mary Anne Tolbert, Perspectives on the Parables: An approach to Multiple Interpretations (Philadelphia: Fortress Press, 1979), 39.

${ }^{89}$ Liz McKinnell, "The Ethics of Enchantment: The Role of Folk Takes and Fairy Tales in the Ethical Imagination," in Philosophy and Literature, 43, no. 1 (2019): 196.

${ }^{90}$ Simone de Beauvoir, "Moral Idealism and Political Realism," in Philosophical Writings, ed. Margaret A. Simons \& Sylvie le Bon de Beauvoir, (Urbana: University of Illinois Press, 2014), 176.

${ }^{91}$ Beauvoir, "Moral Idealism and Political Realism," 176.

92 Tolbert, Perspectives on the Parables, 38. 
the meaning of the parable are necessary so that its meaning does not fall short; the openness of the parable means it can come to life in the hands of an attentive and creative reader but might "recede into terminal dullness" in the hands of another. ${ }^{93}$ As Mary Sirridge points out in their reading of Beauvoir's fiction, we must be receptive to the writer's depiction. ${ }^{94}$ Our interpretation is guided by the overall argument in which the parable is imbedded.

We have seen that freedom is valuable insofar as it takes on a flesh and blood presence in the world. Beauvoir's parable of the sick young woman likewise argues that life itself is not enough; the potential to enact our freedom in the pursuit of aspirations, relationships, and projects is also necessary. Beauvoir writes that "someone told a young invalid who wept because she had to leave her home, her occupations, and her whole past life, 'Get cured. The rest has no importance.' 'But if nothing has importance,' she answered, 'what good is it to get cured?"'95 What good is being healthy if you cannot do anything? What is the point of preserving a life without the potential to pursue plans, aspirations, and meaningful relationships? This parable suggests that ethical action does not only preserve life but does so in a way that affirms "the individual reality of our projects and ourselves." ${ }^{96}$ Ethical actions not only allow us to enact our own freedom; they cultivate circumstances in which others can enact theirs. The concrete and particular thickness of actions, their enactment by us in-the-world and amongst-others, is of the upmost importance.

Beauvoir's parable of the 'American miners' emphasizes this point. Beauvoir writes:

Following a strike, some American miners are condemned to death. Their comrades try to have their trial reconsidered. Two methods are put forward: one can act officially, and one knows that they then have an excellent chance of winning their case; one can also work up a sensational trial with the Communist party taking the affair in hand, stirring up a press campaign and circulating international petitions; but the court will be unwilling to yield to this

\footnotetext{
93 Tolbert, Perspectives on the Parables, 43.

94 Marry Sirridge, "Philosophy in Beauvoir's Fiction," 131.

95 Beauvoir, The Ethics of Ambiguity, 114.

${ }^{96}$ Beauvoir, The Ethics of Ambiguity, 114.
} 
intimidation. The Party will thereby get a tremendous amount of publicity, but the miners will be condemned. What is a man of good will to decide in this case? ${ }^{97}$

Beauvoir lifts this parable from the plot of John dos Passos' The Adventures of a Young Man. In this example, Beauvoir reviews the situation, simulating the ethical decision-making process. If the party is devoted to good of the people, then it cannot abandon miners, but if the party is primarily interested in inciting revolutionary feeling, they should be abandoned. ${ }^{98}$ According to an ethics of ambiguity, saving the miners' lives is the best course of action because it aligns with Beauvoir's imperative to intervene in the lives of others to bring about circumstances in which they can enact their own freedom..$^{99}$ If freedom is to be embodied, the actor must be alive...

What about circumstances in which we find ourselves compelled to impede the freedom of others? Beauvoir's ethical approach maintains that each action depends on its circumstances. For example, Beauvoir writes that "out of disappointment in love a young girl takes an overdose of pheno-barbital; in the morning friends find her dying, they call a doctor, she is saved." ${ }^{100}$ In this case, a young girl has freely chosen to end her life but her friends prevent her from doing so. By saving her life, her friends provide this girl with opportunities for new projects, goals, and passions that Beauvoir suggests she accepts, becoming the "happy mother of a family."101 Beauvoir juxtaposes this parable with another: "in asylums one sees melancholic patients who have tried to commit suicide twenty times, who devote their freedom to seeking the means of escaping their jailers and of putting an end to their intolerable anguish." ${ }^{102}$ Beauvoir writes that the doctor who gives them nice pat on the back is a tyrant and torturer. ${ }^{103}$

\footnotetext{
${ }^{97}$ Beauvoir, The Ethics of Ambiguity, 163.

98 Beauvoir, The Ethics of Ambiguity, 164.

${ }^{99}$ Beauvoir, The Ethics of Ambiguity, 154, 163.

${ }^{100}$ Beauvoir, The Ethics of Ambignity, 154.

${ }^{101}$ Beauvoir, The Ethics of Ambiguity, 154.

102 Beauvoir, The Ethics of Ambiguity, 154

103 Beauvoir, The Ethics of Ambiguity, 154.
} 
Why is one suicide intervention ethical and the other not? Beauvoir's ethic condemns the doctor for not providing their patient with means to enact their freedom. As in the parable of the sick young woman, this doctor neglects to provide their patient with reasons why their life is worth living or the opportunity to actualize those reasons. These parables demonstrate how different circumstances require different courses of action, despite the fact that in each case we follow same imperative: to try and enact our freedom in ways that allow others to enact theirs.

When deliberating a course of action, we must recognize the existence of others, whose freedom is as absolute as our own. ${ }^{104}$ Beauvoir's parables are ethically relevant because they show action in concrete situations. After all, an action "can be judged only by being replaced in the ensemble of the causes it serves." ${ }^{105}$ By thinking about ethical action narratively, we can make sense of its meaning and evaluate it. Parables allow us to process action in this way, but very simply. To really make sense of ethical action in terms of the 'ensemble of causes it serves,' we should consider action with all the added complexity that novel-length narrative provides.

\subsection{Conclusion}

The literary devices Beauvoir employs throughout The Ethics of Ambiguity present ambiguity and freedom as necessarily embodied by simulating a first-person perspective of being-in-the-world and being-amongst-others. First-person plural narration allows readers to adopt Beauvoir's perspective as their own, simulating an experience of being-in-the-world that includes the ambiguity caused by separation. The flesh and blood/bone metaphor introduces the concept of embodied freedom over the course of the text while simulating the meaning making process. Beauvoir's conversational prose and stock characters simulate our limited capacity to overcome ambiguity and her parables demonstrate her ethical approach to freedom. Paying close attention to the

\footnotetext{
104 Beauvoir, The Ethics of Ambiguity, 150.
}

105 Beauvoir, The Ethics of Ambiguity, 158. 
philosophical contributions of Beauvoir's literary devices in The Ethics of Ambiguity demonstrates a coherence between what Beauvoir writes and how she writes it; the text itself facilitates our freedom by inviting us to participate in meaning making.

Presenting freedom and ambiguity in this way challenges the distinction between the philosophical and the literary. The Ethics of Ambiguity demonstrates that philosophy and literature mix, not like oil and water, but like gin and tonic. Does anyone want a drink? 


\section{Intermediary Consideration}

It seems to me that there is no longer this halfway point for literature and philosophy... You're either a philosopher or you're writing literature that might be deep or not. But you're not writing this. You're not writing philosophy as literature. ${ }^{106}$

\subsection{From Essay to Novel}

In the first chapter, we saw how the literary devices in Simone de Beauvoir's essay The Ethics of Ambiguity present freedom and ambiguity as embodied phenomena. The next two chapters build on the first by asking what embodiment means and why it is an important element of Beauvoir's philosophy. They argue that Simone de Beauvoir's novel All Men Are Mortal is an integral part of her oenure because it is both describes her ontology and prescribes her ethics. All Men Are Mortal provides a description of our ontology, which for Beauvoir, is ultimately defined by mortality. Since Beauvoir's conception of freedom is embodied, her ontology cannot be separated from her ethics. Therefore, All Men Are Mortal also provides a prescription of how we should live, which for Beauvoir, is in community with others. Paying close attention to the experiences of Beauvoir's characters reveals how mortality—our common ontological condition—is ambiguous. This ambiguity stems from the idea that mortality is the end and means of our freedom.

This section shifts away from the essay to focus on the novel. The previous chapter concluded with how Beauvoir's parables simulate instances of ethical action. While parables give Beauvoir's readers a sense of action in real time, they lack the complexity of larger narratives. Parables are great means of simulating ethical action in an essay, which has length restrictions; however, novels do not share this limitation. Novels can therefore simulate our experience over extended periods of time.

While both The Ethics of Ambiguity and All Men Are Mortal benefit from the interaction between literary devices and philosophical content, All Men Are Mortal has fewer structural

106 David Pizzaro, “Conceptual Mummies (Nietzsche’s Twilight of the Idols)," Very Bad Wizards, podcast audio, May $12^{\text {th }}, 2020$. 
restraints. As a long narrative, All Men Are Mortal also reflects the structure of cognition insofar as narrative "is the fundamental instrument of thought." 107 This means novels can communicate experience intuitively, unlike forms of writing that lack narrative cohesion. The next two chapters demonstrate how Beauvoir describes our experience through the experience of her characters over time, which she cannot do within the confines of an essay.

\subsubsection{Introducing All Men Are Mortal}

All Men Are Mortal was published in 1946. Beauvoir finished the novel in 1945, immediately before starting The Ethics of Ambiguity. ${ }^{108}$ Both texts were written against the backdrop of the Second World War and address similar themes, including freedom, ambiguity, meaning, and community. In The Ethics of Ambiguity, Beauvoir asks: how do people, originally separate, get together? ${ }^{109}$ As we saw in the first chapter, individuals come together by enacting their freedom through the process of meaning making. Beauvoir elaborates on this question in All Men Are Mortal. The next chapter will demonstrate how All Men Are Mortal allows Beauvoir to articulate a theory of community, of getting together, grounded in our common experience of mortality.

All Men Are Mortal is a hypothetical exploration of mortality and its relationship to community and meaning. The novel begins from the perspective a young French actress named Regina. While on tour in the Provinces, Regina meets an apathetic man named Fosca, recently discharged from an asylum. Regina convinces Fosca to return with her to Paris, where she believes she can cure his apathy. Not long after their return to Paris, Fosca shares a secret with Regina: he is immortal. When Regina becomes obsessed with the thought that her memory will live forever in Fosca's mind, he leaves. Regina follows Fosca to a small café in the village where she grew up, where he recounts the

107 M. Turner, The Literary Mind: The Origins of Thought and Language (New York: Oxford University Press, 1996), 4; Keith Oatley and David Oslon, "Cues to the Imagination in Memoir, Science, and Fiction," in Review of General Psychology 14 no. 1 (2010): 56-64.

108 Arp, The Bonds of Freedom, 40.

${ }^{109}$ Beauvoir, The Ethics of Ambiguity, 17. 
details of his six-hundred-year life. Starting with his youth in medieval Italy, Fosca recounts his experience of the Holy Roman Empire, the European discovery of North America, the Parisian Enlightenment, and Paris during the mid-nineteenth century revolutions. As Fosca's tale unfolds, Regina realizes that immortality is not a gift but a curse. When his story is over, Fosca leaves Regina to come to terms with the unsavory realities his story has unveiled.

Despite its exploration of human experience, All Men Are Mortal is neglected by Beauvoir scholars. Its neglect is possibly related to its departure from the realist mode. All Men Are Mortal is the only one of Beauvoir's novels to include fantastic elements, like immortality, and commentators were not always sure how to tackle this. ${ }^{110}$ It is one thing to entertain realist novels like She Came to Stay and The Mandarins as philosophically or politically relevant, since their realism allows Beauvoir to explore and simulate metaphysical and political experiences. ${ }^{111}$ While fantastic elements like immortality, which are purely hypothetical, do not immediately appear philosophically or politically relevant, their use in All Men Are Mortal allows Beauvoir to explore mortality by juxtaposing it with its opposite: immortality. This method-uncovering how we are by juxtaposing our experience with a rhetorical and hypothetical way of being-is fairly common in political theory.

Beauvoir's method parallels social contract theorists' approach to understanding the human condition. For example, hypothetical, rhetorical devices like the state of nature, social contracts, and metaphors for the state are common in the writings of Thomas Hobbes, John Locke, and JeanJacques Rousseau. These devices allow social contract theorists to freely cross the line separating

${ }^{110}$ Deborah Bergoffen, "Finitude and Justice: Simone de Beauvoir's All Men Are Mortal," in Philosophy Today, 53 (2009): 116.

111 See Carolle Gagnon, "Resistance and Rescue in Beauvoir's The Blood of Others and The Mandarins: A Semiotic Contribution to the Thinking of the 'Being-for-Other' Existential Category," Semiotica 172, no. 1/4 (2008): 233-259; Ashley King Scheu, "The Viability of the Philosophical Novel: The Case of Simone de Beauvoir's She Came to Stay," Hypatia 24, no. 4 (2012): 791-809; Susan Rubin Suleiman, "Memory Troubles: Remembering the Occupation in Simone de Beauvoir's Les Mandarins," French Politics, Culture and Society 28, no. 2 (2010): 4-17; Margaret A. Simons, "Bergson's Influence on Beauvoir's Philosophical Methodology," 107-24; Mary Sirridge, "Philosophy in Simone de Beauvoir's Fiction," 129-149. 
literature from philosophy to articulate their theories of community. We read The Leviathan and The Discourse on Inequality not because they provide us with empirical descriptions of paradise or of a sea monster set loose in rural England, but because their hypotheticals and metaphors allow Hobbes and Rousseau to shine a light on different elements of the human experience. The state of nature and leviathan are similar to Beauvoir's immortality insofar as these hypotheticals shed light on the human experience. By using All Men Are Mortal to describe the human condition and theorize about how and why we enter into community, Beauvoir addresses similar questions using similar methods as thinkers enshrined in the political theory cannon. To neglect All Men Are Mortal because of its fantastic elements becomes a lazy excuse to maintain the boundary between philosophy and literature that we allow other thinkers to cross with reckless abandon.

2.0.2 What's been said about All Men Are Mortal?

The sparse scholarly work on All Men Are Mortal does not consider the philosophical relevance of Beauvoir's imagery nor her characters' experiences imbedded in the larger narrative. Instead, scholars focus on particular concepts or characters abstracted from the novel as a whole. For example, some scholars focus on Fosca or Regina as symbols rather than characters with unique experiences. In "Finitude and Justice: Simone de Beauvoir's All Men Are Mortal," Deborah Bergoffen describes Fosca as a symbol of "the ways in which the desire to deny our finitude for the sake of utopian dreams creates nightmare realities." ${ }^{\text {"12 }}$ Bergoffen points out the ways in which Fosca neglects others in comparison to the novel's other characters, who feel the weight of moral responsibility. However, describing Fosca as a symbol of irresponsibility or neglect ignores the effect of Fosca's indifference on Regina, who is listening to his story. Anne Duchêne likewise neglects Regina in her 1996 review, encouraging readers to muscle through the first section of the novel to reach Fosca's

112 Bergoffen, "Finitude and Justice," 116-117. 
story: "it should be stressed that the opening chapters are fairly dire; set in modern times and involving one of strident monsters of vanity and egoism that France tends to indulge: here, an actress, avid for immortality. It is important not to lose patience, her role steadily dwindles as Fosca tells his story." 113 According to Duchêne, Regina's presence is merely an excuse for Fosca to tell his tale.

Contrarily, Joanna Morrison’s essay “The Actress and Beauvoir: Shining a Light on Regina in All Men Are Mortal,' focuses on Regina. Morrison interprets Regina in light of the stock characters Beauvoir develops in The Second Sex, arguing that Regina's personality at the start of the novel illustrates Beauvoir's feminism. ${ }^{114}$ Nonetheless, presenting Regina as a stock character does violence to the structure of the novel, which depends on the exchange of a story between two people. Each character is treated as prop that symbolizes philosophical ideas articulated elsewhere ${ }^{115}$ missing the potential their experiences have to unveil unique philosophical ideas themselves. In comparison, Julia K. Ward's "Reciprocity and Friendship in Beauvoir's Thought," describes the particular role that relationships play in Beauvoir's thought, drawing examples from Beauvoir's memoirs, She Came to Stay and The Second Sex. The next two chapters builds off of Ward's work on relationships by unveiling the philosophical contribution of characters' experience of others over time.

The overall reluctance of scholars to incorporate the specifically literary elements of All Men Are Mortal, like imagery and experience, into their analyses indicates a larger trend in Beauvoir scholarship. While scholars have included some of Beauvoir's novels in discussions of philosophical ideas, they rarely comment on the role of plot or character development in developing and

113 Anne Duchêne, "A Fabulous Freedom: Simone de Beauvoir All Men Are Mortal," in The Times Literary Supplement no. 4842 (1996): 27.

114 Joanna Morrison, "The Actress and Beauvoir: Shining a Light on Regina in All Men Are Mortal," in Outskirts: Feminism on the Edge 37 (2017): 2.

115 Morrison relies heavily on The Second Sex while Bergoffen relies on The Ethics of Ambiguity. 
articulating those ideas. Instead, scenes are used to illustrate ideas explained elsewhere. This suggests the novel can only be philosophical if its particularly literary elements are ignored.

Even Edward Fullbrook's article "She Came to Stay and Being and Nothingness," isolates concepts like bad faith and human consciousness from the narrative in which they are imbedded. Fullbrook argues that She Came to Stay includes original philosophical ideas later described by existentialist JeanPaul Sartre in Being and Nothingness. ${ }^{116}$ While Fullbrook's work is invaluable in terms of demonstrating Beauvoir's unique and independent philosophical mind, comparing the novel to Being and Nothingness suggests its philosophical status is confirmed by similar ideas appearing later in essay form. This phenomenon is not restricted to She Came to Stay: in "The Actress and Beauvoir," Regina is used to illustrate different attitudes later legitimatized in Being and Notbingness and The Second Sex. ${ }^{117}$

In both essays, characters are treated as symbols of solipsism and bad faith, describing what solipsism or bad faith is without describing why each character presents this way. In other words, neither account for the characters' experiences of the world, which the narrative simulates. Paying close attention to the imagery and experience described by All Men Are Mortal unveils our situation in the world—what we are and how we relate to others—-which has ontological and ethical relevance. While work on Beauvoir's novels neglects the role of experience, the following two chapters fill this gap by paying close attention to Beauvoir's imagery and her character's experiences in All Men Are Mortal.

116 Edward Fullbrook, "She Came to Stay and Being and Nothingness," in The Philosophy of Simone de Beauvoir: Critical Essays, ed. Margaret A. Simons (Bloomington \& Indianapolis: Indiana University Press, 2006), 56-61.

117 Morrison, "The Actress and Beauvoir," 3 \& 4-17. 


\section{Mortality and Lived Experience}

I've often thought about it and I'd say to myself that time could never separate us if only... if only you were my friend. ${ }^{118}$

Le roman est l'histoire de sa lente mais inexorable désillusion. ${ }^{119}$

\subsection{Introduction}

In The Ethics of Ambiguity, Beauvoir writes that "freedom is the source from which all significations and all values spring. It is the original condition of all justification of existence." 120 The first chapter describes embodiment as a necessary condition for freedom. As human beings, our embodiment is subject to our mortality. Thus, Beauvoir's primary philosophical premise turns out to be the title of her novel: all people are mortal. This chapter demonstrates how Beauvoir's conception of freedom flows from this premise. It argues that All Men are Mortal provides a description of our ontology by presenting mortality as both the end and the means of our freedom.

This chapter is split in two sections. The first section argues that mortality is the end of our freedom. ${ }^{121}$ I refer to this conception as 'mortality-as-finitude.' Beauvoir demonstrates mortality-asfinitude by juxtaposing imagery of decay with Regina's experience of anxiety. The second section demonstrates the ambiguity of mortality: it argues that mortality is not only what stops us from enacting our freedom, but also the means of exercising our freedom in the first place. Paying close attention to Fosca's experience of immortality reveals how Beauvoir connects her primary premise, all people are mortal, with the ability to create meaning. In all, Beauvoir's ambiguous description of mortality suggests how to live a meaningful life.

\footnotetext{
118 Beauvoir, All Men Are Mortal, 391.

119 'This novel is the story of his slow but inexorable disillusionment.' My translation. Simone de Beauvoir, "Note de l'auteur," in Tous les hommes sont mortels (Paris: Gallimard, 1946), Kobo e-Book edition.

${ }^{120}$ Beauvoir, The Ethics of Ambiguity, 23.

${ }^{121} \mathrm{By}$ 'end' I mean stop, fin, or finale rather than point, goal, or purpose.
} 
Despite the novel's title, scholars have not focused on mortality in All Men Are Mortal. For example, in their review of All Men Are Mortal and The Mandarins, T.N.F. Murtagh focuses on the concept of 'fête,' arguing it signifies moments of historical or political conjuncture. ${ }^{122}$ In 'Finitude and Justice," Bergoffen focuses on the concepts of political engagement, finitude, and universalism. ${ }^{123}$ While both address productive political questions, when it comes to All Men Are Mortal, mortality is the elephant in the room. Interestingly enough, work that explores Beauvoir's conception of mortality does not draw from All Men Are Mortal. For example, Robin May Schott's article "Beauvoir on the Ambiguity of Evil" presents mortality as an ethical category and ontological fact. ${ }^{124}$ This chapter builds on Schott's argument by expanding its scope to include All Men Are Mortal. By paying close attention to mortality as an ontological fact, we can address the elephant in the room.

Schott points out that Beauvoir, like Martin Heidegger in Being and Time, draws a necessary connection between mortality and ontology. In this sense, Beauvoir provides an alternative perspective to that of her often-compared-to friend and interlocutor Jean-Paul Sartre, for whom mortality and ontology are not necessarily connected. For example, in The Second Sex, Beauvoir writes that

there are conditions without which the very fact of existence would seem to be impossible. Presence in the world vigorously implies the positing of a body that is both a thing of the world and a point of view of the world; but this body need not possess this or that particular structure. In L'Être et le néant (Being and Nothingness), Sartre disputes Heidegger's affirmation that human reality is doomed to death because of its finitude; he establishes that a finite and temporally limitless existence could be conceivable; nevertheless, if human life were not inhabited by death, the relationship of human beings to the world and to themselves would be so deeply upset that the statement 'man is mortal' would be anything but an empirical truth: immortal, an existent would no longer be what we call a man. One of the essential features of man's destiny is that the movement of his temporal life creates behind and ahead of him the

122 T.N.F. Murtagh, "Simone de Beauvoir, 'All Men Are Mortal' and 'The Mandarins' (Book Review)," in Man and World 7, no. 2 (1974): 18.

123 Bergoffen, "Finitude and Justice," 117.

${ }^{124}$ Robin May Schott, "Beauvoir on the Ambiguity of Evil," in The Cambridge Companion to Simone de Beauvoir, ed. Claudia Card (Cambridge: Cambridge University Press, 2003), 230. 
infinity of the past and the future $[. .$.$] a consciousness without a body or an immortal human$ being is rigorously inconceivable. ${ }^{125}$

This passage points to All Men Are Mortal like a neon sign points to a gas station on the side of the highway. It allies Beauvoir with Heidegger against Sartre on the question of mortality. Beauvoir insists that there are some conditions necessary for existence, like a physical presence in the worlda body. Like Heidegger, Beauvoir accepts that the human body is subject to finitude. A life ends with death; mortality-as-finitude defines the outer limits of our existence. On this premise, Beauvoir rejects Sartre's conception of a temporally limitless existence. Beauvoir clearly states that a life unrestrained by mortality would cease to be a human life; therefore, our existence is determined by this one truth. In comparison, immortality is inconceivable.

This passage also succinctly references what Beauvoir demonstrates three years earlier in All Men Are Mortal. Despite its lack of attention, All Men Are Mortal is as relevant to existential discourse on mortality as Heidegger's Being and Time and Sartre's Being and Nothingness. Schott's arguments about ontology would be better served by Beauvoir's novel than The Second Sex, whose purpose is not to define our ontological and ethical condition, but to address the phenomenon of gendered Othering. This passage is not a philosophical explanation of what is illustrated by All Men Are Mortal, but an example of how Beauvoir builds on what the novel establishes to explore other phenomena. All Men Are Mortal describes our ontology as determined by mortality-as-finitude; paying close attention to Beauvoir's imagery of decay and Regina's anxiety will uncover this 'essential feature of our destiny.'

\subsection{Mortality-as-Finitude}

Beauvoir uses imagery of decay to describe mortality-as-finitude, including imagery of grass, insects, and mushrooms. These suggest a close proximity to the earth, decomposition, and recycling

125 Simone de Beauvoir, The Second Sex, trans. Constance Borde \& Sheila Malovany-Chevallier (New York: Vintage Books, 2010), 24. 
nutrients. These images allude to the natural cycle of life and death as a banal phenomenon, ordinary and insignificant. For example, feeling particularly anxious about the finitude of her life, Regina

looked down at the lawn. It was an old, familiar pain. She would be lying on a similar lawn, her cheek pressed against the ground. Insects were scurrying about in the shade of the grass, and the lawn became an immense, monotonous forest in which thousands of little green shoots, all the same size, all alike, were concealing the world from one another. In anguish, she had thought, 'I don't want to be just another blade of grass. ${ }^{126}$

Regina's anguish stems from being ordinary, one of thousands. By imagining Regina lying on the grass amongst the insects, Beauvoir parodies the decay of a dead body. Regina's desire to avoid becoming another blade of grass not only betrays her aversion to ordinariness but connects that aversion to one of death. This suggests that Regina's anguish stems from being subject to the same natural laws as everyone else. Like everyone else, Regina will die, crawling with insects, sinking into the earth to be re-appropriated as the nutrients necessary for plant life. She will inevitably become a blade of grass. ${ }^{127}$ What concerns Regina is not only her inevitable come-back in plant form, but that it happens to everyone. She is not special; she is one amongst many. Regina's anxiety stems from the possibility of being as insignificant in life as we become in death.

Beauvoir continues to demonstrate mortality-as-finitude with insect imagery. Both Regina and Fosca think of people as insects. Like insects, who appear to scurry around senselessly until they die, Regina and Fosca see us as running out the clock. For example, in comparison to Fosca, Regina considers herself "nothing but some insect." 128 Likewise, Fosca observes that "the Genoese, those little black ants that were scurrying about their tents, would also die." ${ }^{29}$ Five hundred years later, Fosca's metaphor is unchanged: "the ants came and went, thousands of ants, thousands of times the

126 Beauvoir, All Men Are Mortal, 7.

${ }^{127}$ Unless she is cremated and scattered in the sea, in which case seaweed is more likely.

${ }_{128}$ Beauvoir, All Men Are Mortal, 31-32.

${ }^{129}$ Beauvoir, All Men Are Mortal, 103. 
same ant. They came and went out of the offices of the Réforme. They walked over to the window, they walked away, slapped each other on the shoulder, sat down, got up, and they prattled ceaselessly." ${ }^{130}$ Both Regina and Fosca think individuals amount to nothing more than indistinguishable beings ceaselessly moving in seemingly absurd circles, running out the time before their inevitable death and decay. According to Regina and Fosca, mortality-as-finitude renders human life pointless.

Beauvoir also demonstrates mortality-as-finitude with the image of a stagnant, immobile mushroom. Fosca's son Antonio is the first to invoke the mushroom. Antonio uses it to describe the city of Carmona, which Fosca rules. He asks Fosca, "what good is all our wealth, our culture, our wisdom, if we remain here planted on our rock like a giant mushroom?"131 After Antonio's death, Fosca adopts his son's simile: "suddenly nothing seemed important anymore [...] Carmona would continue to vegetate under the sky like a giant mushroom." ${ }^{\prime 132}$ When Fosca leaves Carmona to seek his destiny elsewhere, he thinks of it with distain, as "nothing but a huge mushroom." 133 Fosca thinks that which is like a mushroom should be abandoned. It is unimportant, unchanging, and reviling.

Mushrooms are immobile lifeforms whose growth depends on the uptake of dead and rotting organisms. This makes it a symbol of stagnation, decay, and recycling. By comparing Carmona to a mushroom, Fosca implies it is incapable of progress and destined to exist amongst rot. Like pointless insects and indistinguishable blades of grass, it is something to turn your back on. By comparing human life to grass, insects, and mushrooms, Beauvoir emphasizes inevitable death and decay of living bodies. With these images, Beauvoir describes mortality-as-finitude as natural and

130 Beauvoir, All Men Are Mortal, 393.
131 Beauvoir, All Men Are Mortal, 151.
132 Beauvoir, All Men Are Mortal, 157.
133 Beauvoir, All Men Are Mortal, 168. 
universal. Regina's anxiety betrays the uncomfortable reality of death-as-finitude; our ontological state imposes a limit on the upper reaches of our lives, our freedom. After death, there is nothing we can do.

There is a subtle difference in the effect of Beauvoir's imagery of decay that depends on each character's perspective. For Regina, imagery of decay causes aversion. For Fosca, these images betray his incomprehension. The difference stems from their ontological realities; as a mortal person, mortality-as-finite causes Regina anxiety. For immortal Fosca, human life appears absurd or incomprehensible, like ants swarming an anthill. Fosca can turn his back on mortality-as-finitude because it does not define his being. For Regina, mortality-as-finitude is a nauseating embarrassment that contains the risk of insignificance, which she sees as a personal failure.

Regina sees mortality-as-finitude as a tragic end to her capacity be significant. For example, Regina "hated these anonymous hotel rooms [...] where she herself would need no trace. 'Everything will be exactly the same, except I won't be here anymore. That's what death must be like,' she thought. 'If only one could leave an impression of oneself in the air, where the window howled as it rushed in. But no! Not a ripple, not a rift."134 In this passage, Regina's hotel room symbolizes death. Like other guests before her, evidence of Regina's presence will be removed upon her departure. Likewise, Regina's death will erase her presence from the world. Of course, this is not technically true. Regina's body will remain for a time, but it will no longer offer Regina a point of view. The presence of Regina's consciousness is therefore not determined by her body but her mortality. By cutting off her freedom, death prevents her from being able to leave a lasting impression though her body remains behind.

Regina wishes she could leave an impression of herself in the air like the wind. This imagery invokes the separation of body and consciousness. Like wind, perhaps consciousness can float

134 Beauvoir, All Men Are Mortal, 13. 
around, supported by nothing but pure energy. Beauvoir denies this possibility: not even a ripple will remain. This passage alludes to Sartre's conception of the temporally limitless existence that Beauvoir explicitly rejects in The Second Sex. This passage describes consciousness as inseparable from the body and in the actualization of our mortality-as-finitude (death), it ceases to exist. This passage describes mortality-as-finitude as the ultimate end to freedom by ending embodied consciousness. Regina sees this as a tragedy.

Fosca also considers mortality-as-finitude a tragedy; so, he re-wrote its ending. Standing in his besieged castle and looking out at the Genoese, mortal Fosca thinks 'I'm here now, but one day I'll no longer be here. I won't be anywhere... It will happen from behind and I won't even know it happened [...] no, it's impossible. It can't happen to me, not to me!'135 This short reflection demonstrates that Fosca has both a fear and denial of his mortality. Just like in the passage above, Beauvoir uses Fosca's reflection on his mortality to emphasize the essential connection between Fosca's consciousness and mortality-as-finitude: no life, no consciousness. While Fosca re-writes his story by altering his ontology to become immortal, Regina attempts to overcome her mortality through memory.

Regina's motivation throughout All Men Are Mortal's prologue is to overcome mortality-asfinitude, which she believes can be done via Fosca's immortal memory. If Fosca remembers her, then an impression of her will remain after her death. In The Ethics of Ambiguity, Beauvoir writes that some obstacles may be overcome, but not others: "in the face of an obstacle which it is impossible to overcome, stubbornness is stupid." ${ }^{136}$ Beauvoir continues to specify that "if I persist in beating my fist against a stone wall, my freedom exhausts itself in this useless gesture without succeeding in

135 Beauvoir, All Men Are Mortal, 94.

${ }^{136}$ Beauvoir, The Ethics of Ambiguity, 28. 
giving itself content." ${ }^{\prime 137}$ Unfortunately for Regina, Beauvoir describes the ontological reality of mortality-as-finitude as an insurmountable obstacle. Regina's attempts to overcome it are pointless.

Comparing Regina’s attempts to overcome mortality-as-finitude to political theorist Hannah Arendt's concept of 'action,' further reveals the futility of her behaviour. Arendt describes her conception of action in The Human Condition. She uses the word 'actor' figuratively to describe a certain type of being-in-the-world; 'action' is what remains of us in the world after our deaths.

Action requires speech. Arendt writes that a life without speech is "literally dead to the world; it has ceased to be a human life because it is no longer lived among [people]." ${ }^{138}$ Like what Beauvoir demonstrates through the use of dialogue and stock characters, Arendt argues that speech defines the human condition as being-amongst-others. ${ }^{139}$ This means that action, which relies on speech, takes place amongst the pre-existing relationships and structures of the lifeworld. The complexity of these structures, and the presence of others, means that "action almost never reaches its purpose."140 Therefore, action is not something we create with intention. Our living reality is often different from what others will derive from our life stories after our deaths. ${ }^{141}$

Regina tries to achieve action, to overcome mortality-as-finitude, by ensuring her own legacy in Fosca's memory. ${ }^{142}$ Arendt tells us this is impossible because action is revealed through the retrospective meaning making of others. ${ }^{143}$ However, if Fosca witnesses Regina's experience, perhaps he can ensure her life story continues: "for him, all those diverse destinies comprised one single story, and Regina was now a part of that story." ${ }^{144}$ Through Fosca, Regina believes she will overcome mortality-as-finitude by achieving lasting impact. Through Fosca, she hopes to achieve Arendtian

\footnotetext{
${ }^{137}$ Beauvoir, The Ethics of Ambiguity, 28.

138 Arendt, The Human Condition, 176.

139 Arendt, The Human Condition, 178.

140 Arendt, The Human Condition, 184.

141 Arendt, The Human Condition, 184

142 Beauvoir, All Men Are Mortal, 43.

143 Arendt, The Human Condition, 192.

144 Beauvoir, All Men Are Mortal, 43.
} 
action; however, Beauvoir denies this possibility. When Regina's old boyfriend Roger confronts

Regina about her obsession with Fosca's memory, she explains:

'I need him [...] Ten thousand years from now, someone will still remember me.'

'He'll forget you.'

'He says he never forgets anything,' replied Regina.

'Then you'll be there, pinned in his memory like a butterfly in a collection. ${ }^{145}$

By pointing out to Regina that her memory will exist in Fosca's mind like a butterfly in a collection, Roger suggests Regina's efforts will culminate in her biggest fear: becoming an insect, immobile and insignificant. Though Arendt's conception of action provides a comfort against the anxiety inducing realities of mortality-as-finitude, it is not a valuable concept for the actors. Action, or any conception of legacy or legend, is as useless to the actor as a butterfly collection is to a dead butterfly. In terms of creating a meaningful life, action is not useful. Despite Regina's best efforts, Beauvoir's description of mortality-as-finitude demonstrates that being an actor does not add any value to our lived experience - in fact, since 'actor' is a post-mortem designation, to be an actor is impossible.

All Men Are Mortal denies the value of our own action, legacy, and memory insofar as they are inaccessible us, yet Beauvoir goes one step further to describe how mortality-as-finitude is related to memory of others. After the death of his wife, Fosca pledges to keep her in his memory forever; however, about one hundred years after her death, the world is so changed that her memory is no longer relevant. Looking around eighteenth-century Paris, Fosca thinks:

To have remained here by my side, Marianne would have had to stop being herself [...] It was no longer Marianne's world and I could no longer contemplate it through her eyes. The image of her face was now snuffed out completely; and her heart had stopped beating, even in my own heart. 'You'll forget me.' It was not I who had forgotten her. She had slipped out of the world, and she slipped out of me who would never leave this world. There was no trace under the sky, neither on the waters nor on the earth, no trace in my heart; there was no void, no absence, everything was full. ${ }^{146}$

145 Beauvoir, All Men Are Mortal, 45.

146 Beauvoir, All Men Are Mortal, 197. 
Despite his immortality, Fosca is incapable of maintaining Marianne's memory. As the world changes, her presence is erased. But there is 'no void, no absence, everything was full;' there is nothing left of Marianne or the world in which she lived, and this is okay. Over time, everything that connects our memory to the world will change as others embody their freedom to pursue new goals. Marianne's goals, her preferences and values, no longer have a place in the world. Fosca's immortality allows him to experience this shift, but our mortality-as-finitude ensures that we, and those who would remember us, do not. This ensures that our memory never becomes meaningless by outlasting its situation. To try and secure a legacy that would is a waste of our freedom.

To feel anxiety or aversion in reaction to mortality-as-finitude is not an irrational response. Through imagery of decay, Beauvoir describes mortality-as-finitude while inculcating the same anxiety, anguish, and nausea in her readers as Regina feels. ${ }^{147}$ This sense of unease is compounded by Beauvoir's insistence on the futility of overcoming mortality-as-finitude through memory. The interdependence of consciousness and body makes it impossible to participate in meaning making after death; the activities of others change the world. If we could leave an imprint of ourselves on the air, it too would vanish over time.

Repulsion, anxiety, and meaninglessness... Beauvoir's description of mortality-as-finitude in All Men Are Mortal is similar to both Heidegger and Sartre's descriptions of being-in-the-world. In Being and Time, Heidegger describes how our ontological situation, defined by finitude and nothingness, causes anxiety, which is in turn our motivation for action. ${ }^{148}$ Building on Heidegger, Sartre writes in Being and Nothingness that facing this nothingness causes chronic anguish. ${ }^{149}$ Beauvoir's ontology builds on both. For Beauvoir, while mortality-as-finitude is part of our ontology, our

${ }^{147}$ Beauvoir, All Men Are Mortal, 78.

${ }^{148}$ Martin Heidegger, Being and Time, trans. Dennis J. Schmidt (Albany: State University of New York Press, 2010), 266.

${ }^{149}$ Jean-Paul Sartre, Being and Notbingness, trans. Hazel E. Barnes (New York: Washington Square Press, 1992), 50. 
experience is not necessarily characterized by anguish. Beauvoir's ontology also provides us with a description of how to fill nothingness. All Men Are Mortal does not only describe mortality-asfinitude, but as the means of enacting our freedom and therefore as a source of meaning. The next section focuses on this less anxiety-inducing aspect of our mortality.

\subsection{Mortality-as-Means}

This section argues that All Men Are Mortal not only describes mortality-as-finitude, or the end of freedom, but also as the means of our freedom. Beauvoir's conception of freedom as embodied implies that a physical presence in the world (a body) is the only condition necessary to enact our freedom. This is not the case; the previous section revealed that according to Beauvoir, mortality, rather than our physical presence, defines our existence. This section builds on the previous to uncover a second, productive relationship between mortality and freedom. Paying close attention to Fosca's experience of immortality reveals how our ontological condition provides the means of exercising our freedom and therefore the means of living meaningful lives. While Fosca has a physical presence in the world, he lacks complete freedom.

If all people are mortal, then our ontology provides us with a common situation. This common situation provides a foundation upon which we can build relationships and these relationships facilitate the process of meaning making. This process allows us to enact our freedom, which allows us to make more meaning: meaning making and enacted freedom (action) are therefore co-dependant and mutually re-enforcing. The more we act, the more meaning is made, which inspires more action, et cetera. This means that, not only is mortality the means of exercising our freedom, but the necessary condition for a meaningful life. Mortality provides the means of freedom, meaning, and community. 
By providing a description of mortality as the means of freedom, Beauvoir answers the question she articulates in The Ethics of Ambiguity as "how do [people], originally separate, get together?"150 Playing close attention to Fosca's experience reveals how our mortality provides a foundation for getting together. Beauvoir's story also suggests why we get together: to build meaningful lives. By juxtaposing Fosca's immortality with mortality, Beauvoir proposes both a how and a why of community formation.

\subsubsection{Ontology is a community catalyst.}

The previous section detailed how Beauvoir's imagery of decay and Regina's anxiety describes mortality-as-finitude as a common ontological condition. In order to reveal how mortality provides the means of our freedom, we must begin from the same premise: all people are mortal. Our ontological condition acts like a catalyst for community in the sense that separate people do not have to get together, but if we choose to, our common ontological situation helps facilitate the process. Mortality provides a common ground upon which we can get together.

Fosca does not stand on common ground. Fosca confesses that "what [he] liked most was witnessing a man struggling with himself. Nothing was forcing him to kill himself, if he did not want to die, he only had to decide: 'I will not kill myself."'151 Fosca is fascinated by and jealous of others' mortality. ${ }^{152}$ Reflecting on mortality, he thinks, "all those I had ever loved—were dead, and I went on living [...] A mortal man could have refused to continue on this way, could have made his rebellion eternal: he could have killed himself. But I was the slave of a life that dragged me inexorably towards indifference and oblivion." ${ }^{153}$ Unlike others, Fosca does not have the capacity to choose between life

\footnotetext{
${ }^{150}$ Beauvoir, The Ethics of Ambiguity, 17.

151 Beauvoir, All Men Are Mortal, 284-285.

152 Beauvoir, All Men Are Mortal, 271-272, 284-285, 286.

153 Beauvoir, All Men Are Mortal, 334.
} 
and death. Rather than mortality-as-finitude, Fosca experiences immortality-as-infinitude. Fosca's ontological difference, his... inhibited mortality, makes him a perpetual outsider.

As Fosca continues to experience immortality, he becomes increasingly aware of his difference. At an eighteenth-century Parisian salon—around age five hundred-Fosca reflects on the fact that his difference is not a result of his aging, but the result of his being: others "were small and puny, and they would have cut a sad figure in Carmona or at the court of Charles V... In my time, horses galloped across plains, we held lances in our hand. In my time... Suddenly I thought, 'But isn't this also my time?"'154 In this moment, Fosca realizes that by virtue of his immortality, he does not have 'a time,' a distinct situation defined by the beginning and end of his life. Instead of belonging equally to all time, Fosca's immortality ensures his perpetual difference. He thinks, "there was no other land for me but this planet where I felt I no longer belonged. I had been at home in Carmona and in the court of Charles V, but that was long before. Henceforth, the years that would stretch out endlessly before me would be years of exile." ${ }^{155}$ Rather than living like an eternal time chameleon, adapting to any situation, Fosca's immortality marks him as eternally different. As long as he is immortal, Fosca lacks a basic, common situation shared by others. His belonging is an illusion.

Fosca's experience of homelessness mirrors Heidegger's description of being-in-the-world as 'uncanny.' Uncanniness [Unheimlichkeit] describes the experience of uncovering the sinister or uncomfortable nature of a space you previously found comfortable and familiar. ${ }^{156}$ In Being and Time, Heidegger presents this as the universal experience of being-in-the-world; ${ }^{157}$ while uncomfortable, the uncanny recognition of nothingness motivates our action. By invoking this concept in Fosca's experience, Beauvoir inverts Heidegger's description. She suggests that an experience of

154 Beauvoir, All Men Are Mortal, 278-279.

155 Beauvoir, All Men Are Mortal, 281.

156 See Sigmund Freud, “The Uncanny," in New Literary History, 7 no. 3 (1976): 623-624.

${ }^{157}$ Heidegger, Being and Time, 266. 
uncanniness, anxiety, and discomfort is not the defining feature of mortal being-in-the-world, but of immortal being-in-the-world. Rather than being associated with action, Beauvoir associates anxiety with inhibition. By flipping Heidegger's description, she suggests we can feel at home in the world. Fosca's condition is one of permanent difference and discomfort, but we are not necessarily resigned to the same experience. Anxiety is a mortal experience, but it is not necessarily the mortal experience.

Fosca's ontological difference means he lacks a common foundation upon which we can build relationships. As a result of his immortality, his relationships with other people fail again and again. For example, Fosca's immortality causes his friend Carlier to resent him. On an expedition to relocate a fictitious river than runs from The Great Lakes to Florida, Fosca and Carlier experience a series of unfortunate events. Left stranded without shelter or provisions, Carlier turns against Fosca, who, as an immortal, can survive their situation. While Carlier previously thought the two were in it together, their dismal situation reveals this to be false. Carlier realizes, unlike Fosca, that he cannot survive. When Fosca offers to go find provisions, her replies,

'I'm staying here. Goodbye.'

'I'll stay with you.'

'No, leave me alone.'

'I'm staying,' [Fosca] insisted [...]

'Go,' he pleaded. 'I don't want to die with you looking at me.'158

Carlier's resentment of Fosca's immortality has grown to the point where death is preferable to his help. Fosca walks away and later recounts, "I heard a single gunshot. I did not move. 'For him, it's over,' I thought. 'But for me will it never be possible to relinquish this body of mine and leave behind only a few, bare bones?"'159 Carlier's death cements Fosca's awareness of his ontological difference.

158 Beauvoir, All Men Are Mortal, 271.

159 Beauvoir, All Men Are Mortal, 271. 
Fosca's relationship with Carlier is not his only relationship to turn sour as a result of his immortality. When Fosca's wife Marianne discovers his immortality (which he hid for the majority of their marriage), she is betrayed. Fosca's ontological difference eviscerates the meaning of their marriage. He tries to convince Marianne that his immortality does not change their relationship; he tries to convince her that his memory will immortalize their love. Marianne disagrees: "Oh, I know you'll forget me. And it's probably better that way. They must weigh heavily on you, all those memories [...] If you were mortal, I'd go on living in you until the end of the world. Instead, I am going to die in a world that will never end." ${ }^{160}$ Marianne's response mirrors Roger's warning to Regina: those remembered by Fosca exist in his memory like dead butterflies pinned in a collection. To die in a world without end, for Marianne, is to be reduced to a dead fact. If Fosca were mortal, her memory would have meaning forever, insofar as our 'forever' is determined by mortality-asfinitude. Marianne resents Fosca's immortality because it renders her memory meaningless and irrelevant over time. Fosca's failed relationships with both Carlier and Marianne demonstrate how his ontological situation prevents him from participating in meaning making over time.

\subsubsection{Meaning is not made in a vacuum.}

The first chapter demonstrated how communication between two or more people facilitates meaning making. This communication presupposes a relationship between participants: to communicate we need to get together. Without these relationships, Fosca cannot participate in meaning making. Relationships are meaningful, therefore, if as they create meaning. Inversely, meaning making does not occur in isolation. ${ }^{161}$ Beauvoir demonstrates this by drawing an association between Fosca's difference and meaninglessness. For example, Fosca's first family dies of the plague in the fourteenth century. At their funeral, he thinks, "My past was buried [...] I was without the law,

\footnotetext{
${ }^{160}$ Beauvoir, All Men Are Mortal, 330-331.

${ }^{161}$ Beauvoir, The Ethics of Ambiguity, 21; Maurice Merleau-Ponty, "Indirect Language and the Voices of Silence," 44-45.
} 
I was my own master, and I could dispose as I pleased of poor human lives that were doomed to die. Under the featureless sky, I drew myself up erect, feeling alive and free, and knowing I would forever be alone."162 This reflection emphasizes Fosca's ontological difference: his friends are gone; he is alone of his kind; his past is inaccessible. Since he is alone, both physically and ontologically, he is no longer subject to the same social expectations as others. Fosca considers this a negative freedom, like the featureless sky above him, there is nothing that can limit or qualify his actions: no sun, no clouds, no laws, no expectations. While Fosca might enjoy a certain degree of negative freedom due to his difference, his freedom is not complete. There are somethings he cannot do: Fosca is not free to enter into relationships with others, he cannot create meaning. Thus, Fosca lacks a positive freedom that community provides.

While Beauvoir uses the death of Fosca's family to draw a connection between ontological difference and meaninglessness, she uses Fosca's initial encounter with Carlier to demonstrate how entering into relationship with others brings about meaning. Hearing Carlier's shouts from the other side of a river awakens Fosca from one hundred years of solitude:

'Hello! Hello!'

I gave a start. It was a human voice, the voice of a white man.

'Hello! Hello!' I shouted back. [...]

Between us, through the night, a dialogue had begun [...] Suddenly, on the bank of the river, I found myself once more with a past, a future, a destiny. ${ }^{163}$

Just as the conversational quality of The Ethics of Ambiguity simulates our experience of meaning making through speech, this dialogue reveals Fosca and Carlier's subjectivities to each other. Fosca thinks, "the man who was sleeping on the other bank knew where I was."164 Starting a dialogue with Carlier not only returns Fosca to being-amongst-others, it also constitutes his awareness of himself:

162 Beauvoir, All Men Are Mortal, 119.
163 Beauvoir, All Men Are Mortal, 246.
164 Beauvoir, All Men Are Mortal, 247. 
Fosca's life becomes more meaningful with Carlier in it. Fosca's initial encounter with Carlier demonstrates how meaning depends on being-amongst-others.

Even though the friendship between Fosca and Carlier disintegrates, it demonstrates the important role that relationships play in Beauvoir's thought. In "Reciprocity and Friendship in Beauvoir's Thought,' Julia Ward emphasizes the importance of reciprocity for meaningful relationships. Ward argues that for Beauvoir, relationships of reciprocity are the ultimate ethical relationships because they lack power dynamics. All participants play on a level playing field and benefit equally. Ward uses the example of female friendships from Beauvoir's autobiographies, which may include a lesser power dimension than present in male-female friendships. ${ }^{165}$ In this sense, femininity defines the level playing field, the common situation. In All Men Are Mortal, it is ontology, rather than gender, that defines the common situation. Since Carlier and Fosca do not share a common ontological situation, their relationship fails. Their difference causes a power dynamic they cannot overcome. In the end, Carlier and Fosca demonstrate how relationship is a necessary condition for meaning making but needs a common foundation to be successful.

Beauvoir presents relationships with others as the source of meaning, as long as participants share a common situation. When working with his great-grandson Armand for the revolutionary effort in 1830s Paris, Fosca struggles to understand why Armand would commit to a cause whose end he might never see. Armand responds that they are "well aware that after that other [people] will have other, new requirements" in the future. ${ }^{166}$ The value of Armand's actions does not depend on future success, on changing the human condition permanently for the better, but on his community. Armand says to Fosca, "I'm one of them [...] That Carmona should have been great and free for two hundred years doesn't matter to you much today. But you know very well what Carmona meant

\footnotetext{
165 Julia Ward, "Reciprocity and Friendship in Beauvoir's Thought," The Philosophy of Simone de Beauvoir, ed. Margaret A. Simons (Bloomington \& Indianapolis: Indiana University Pres, 2006), 152.

${ }^{166}$ Beauvoir, All Men Are Mortal, 385.
} 
to those who loved her [...] You find the worker's conditions abominable. Well, think of those workers you have known personally, only of them." ${ }^{167}$ Armand reveals the importance of relationality.

From Fosca's immortal perspective, relationships and projects are small blips on the endless timeline of history. Contrarily, Armand emphasizes that we are not just being-in-the-world, but being-amongst-others, and by acting for and with others our freedom generates meaning. Armand's work aims to benefit himself and those workers he knows personally; any future benefits are irrelevant or at least, an added bonus for others. But whether Armand's action is beneficial will be up to them, not him. Mortality defines the outer limits of our existence while providing a time between birth and death when freedom is possible. ${ }^{168}$ Fosca's immortality means he lacks life's outer limit, which impedes his ability to appreciate the here-and-now.

Fosca's ontological situation therefore prevents him from participating in meaningful relationships in the present. His immortality means he sees the incessant future as more real than his present. Fosca withdraws. He refuses the offer of friendship from an eighteenth socialist named Laura, with whom he is working:

'If you want,' she said, 'I could be your friend.'

'You don't understand,' I said. 'No one can understand who I am, what I am.' [...]

'One day you'll be dead and I'll forget you.' I said. 'Doesn't that make friendship impossible?' 'No,' she replied. ${ }^{169}$

Just like his initial encounter with Carlier, talking with Laura opens Fosca up to the possibility of a meaningful existence. However, this potential quickly fizzles out as he remembers how over time, others vanished from the world. Laura's mortality will ensure it happens to her. Fosca's difference, and its subsequent meaninglessness, triumphs. Fosca thinks, “'There’s no point. Everything is

\footnotetext{
167 Beauvoir, All Men Are Mortal, 386-387.

168 Beauvoir, All Men Are Mortal, 387

${ }_{169}$ Beauvoir, All Men Are Mortal, 391-392.
} 
pointless.' [...] Laura was already dead. I withdrew my hand from hers. [...] I would have had to love her. I did not love her. I wanted nothing." ${ }^{\text {170 }}$ In this case, rather than sabotage his relationship, Fosca's immortality prevents him from entering into it in the first place. Without a common situation, Fosca is immobilized; he knows his relationship will bring about nothing and so nothing is all he can expect.

What is particularly tragic about Fosca's immortality is that it not only prevents him from achieving something, but it causes him to want nothing. Fosca does not want to enter into relationships just to watch them end in resentment and death. Over time, Fosca prefers isolation to the pain of perpetual abandonment. Remember Heidegger and Sartre's descriptions of being-in-theword; it is a painful experience of nothingness. ${ }^{171}$ Fosca's experience suggests that being-in-the-word can be painful but this pain might be alleviated by being-amongst-others, through the process of meaning making. By choosing immortality, Fosca condemned himself to the painful experience of meaninglessness without a means of escape. He cannot end it through death, nor can he overcome it through the process of meaning making. We, on the other hand, have the ontological tools necessary to mitigate some of this pain.

3.2.3 Meaning making and freedom establish a positive feedback loop.

Our mortality provides a common situation upon which we can build relationships. We enact our freedom to enter into a relationship and that relationship becomes a space to enact freedom. Since they are co-dependent, Fosca's immortality inhibits both his freedom and his ability to create meaning. As a result, while others can find meaning in the world, Fosca finds emptiness: "at times it seemed as if the world belonged to me alone, as if none of its transitory visitors could ever dispute it with me. But there were other times when, seeing the love which they bore it, I had the feeling that

170 Beauvoir, All Men Are Mortal, 393-394.

171 Sartre, Being and Nothingness, 50-51, 82-83; Heidegger, Being and Time, 266-267. 
I was the one for whom it was dead and faceless. I was riveted to it, and yet I was excluded." 172

Fosca's embodiment eternally connects him with the world, yet he cannot qualify this experience. He reflects that "for me, on this earth to which I was eternally bound, happiness meant no more or less than unhappiness, hate as insipid as love. There was nothing anyone could do for me." ${ }^{173}$ Fosca is in the world, but not among others. As a result, words lose their meaning; "words don't have the same meaning for you as they do for me [...] how can I possibly know what they [others] believe to be good or bad for themselves?"174 Fosca no longer speaks a shared language.

Since Fosca cannot enter into relationships, he cannot enact his freedom. As a result, Fosca's world drains of meaning. For example, after leading a successful military campaign in Rome, Fosca remembers that as a mortal man, if Rome was sacked, he "would have shed tears" but when it happens, he thinks, "in her destruction I saw neither victory not defeat, only a meaningless fact. [...] I no longer knew what it was like to suffer or rejoice: a dead man."175 This passage describes how Fosca's freedom lacks meaning-generating capabilities. By comparing Fosca to a dead man, Beauvoir invokes her conception of mortality-as-finitude: like a dead man, Fosca cannot enact his freedom. Of course, Fosca is not a dead man; Fosca is alive, yet he cannot generate meaning. Once again, we see how Beauvoir's conception of freedom is positive: our mortality provides us with the circumstances in which we enact our freedom. According to Beauvoir, if we cannot create meaning, we cannot be totally free. Freedom does not merely depend on a lack of obstacles, but on mortality, which determines the outer limits of our embodiment and provides opportunities to participate in meaningful relationships with others.

172 Beauvoir, All Men Are Mortal, 261.

173 Beauvoir, All Men Are Mortal, 286.

174 Beauvoir, All Men Are Mortal, 390.

175 Beauvoir, All Men Are Mortal, 207. 


\subsection{Conclusion}

Paying close attention to Fosca's experience over the course of All Men Are Moral reveals the ambiguous nature of mortality. While Beauvoir's imagery of decay describes mortality-as-finitude, Fosca's experience reveals our mortality to also be the means of exercising our freedom. Beauvoir's novel allows mortality to have multiple meanings at once, reflecting our experience while also contributing to our understanding of existential ontology dominated by Heidegger's and Sartre's anxiety-inducing descriptions of being-in-the-world. All Men Are Mortal describes mortality as our ontological reality; a common situation upon which we can build relationships. These relationships in turn provide the opportunity to exercise our freedom and create meaning. Entering into community with others-being-amongst-others - is therefore a necessary step towards living a meaningful life.

Beauvoir's description of mortality as the means of freedom therefore not only contributes to existential ontology but to existential ethics. All Men Are Mortal not only describes meaning as the means by which people, originally separate, get together, but why they would want to get together in the first place. Fosca's experience describes isolation as meaningless. Thus, All Men Are Mortal implies that we should live with others if we want to live meaningful lives. The next chapter will explore the ethical implications of Beauvoir's ontology through a close reading of Regina's

experience of Fosca's life story. While Fosca's immortality dooms him to an absurd existence, Regina's—and our—mortality ensures we never have to suffer the same meaninglessness. 


\section{Coming of Age and Lived Experience}

On the last page, she is seen screaming, presumably at the human condition, likely at immortality... ${ }^{176}$

...le lecteur en prend progressivement conscience avec Fosca, il y a illusion tragique à croire qu'une existence humaine aurait tout à gagner en acquérant la dimension d'immortalité. ${ }^{177}$

\subsection{Introduction}

The previous chapter argued that Beauvoir describes mortality as our common ontological situation. As such, it is both the end and the means of our freedom, defining the outer limits of our capacity for action while serving as a common foundation upon which we can get together to create meaningful lives. This embodied experience is ambiguous because it holds multiple meanings at once. Beauvoir describes this as a layering, or collage, of meaning:

if I am writing a novel I can very well sustain these two themes at the same time, as one sustains several themes at the same time in a symphony or sonata, in counterpoint, by mixing them and making them exist together by having them support each other [...] This is the advantage of a novel: one can put forth two opposing points of view, keeping them in balance [...] It says nothing but shows a whole set of difficulties, ambiguities, and contradictions which constitute the meaning of lived existence. ${ }^{178}$

Writing in literary form allows Beauvoir to describe experience from multiple perspectives. This chapter shifts to Regina's experience of Fosca's story, demonstrating how each definition of mortality exists in the world simultaneously, though experienced differently, at different times, by different people.

Multiple perspectives and their associated meanings are a particular benefit of literary form. As argued in chapter one, literary form simulates being-amongst-others. This state is affective; when we are in community with others, their actions and speech effect our behaviours and understanding,

\footnotetext{
176 Dûchene, “A Fabulous Freedom,” 27.

177 '... the reader gradually becomes aware alongside Fosca that it is a tragic illusion to believe humanity has anything to gain by acquiring immortality.' My translation. Beauvoir, "Note de l'auteur," Kobo e-Book edition.

178 Simone de Beauvoir, "My Experience as a Writer," in "The Useless Mouths" and Other Literary Writings, ed. Margaret A. Simons \& Marybeth Timmerman (Urbana: University of Illinois Press, 2011), 286.
} 
while ours effect theirs. ${ }^{179}$ Literature can simulate this state through conversation and interaction between characters. Characters tell stories to each other and are affected by the stories they hear.

One common form of such storytelling is embedded narrative. Examples include epistolary novels, which consist of letters sent from one character to another, narrative collages, which consist of multiple vignettes or episodes, and story-within-a-story narratives. ${ }^{180}$ In these cases, embedded narratives are driven by the communication of subjective points of view between characters. It is generally acknowledged that the popularity of embedded narratives since the eighteenth century reflects the modern turn towards subjective experience as a legitimate means of understanding the world. ${ }^{181}$ By incorporating storytelling between characters, embedded narratives legitimize the value of subjective, embodied experience while simulating the affective nature of being-amongst-others. Embedded narratives reflect Beauvoir's larger phenomenological method: to describe the world from an embodied first-person perspective.

All Men Are Mortals narrative progression depends on such storytelling, specifically, the storywithin-a-story. All Men Are Mortals prologue and epilogue are written from Regina's perspective while parts one through five consist of Fosca's storytelling and Regina's reactions. Paying attention to how Fosca's story affects Regina's behaviour reveals how the story-within-a-story can be an effective philosophical tool. By writing a story-within-a-story, Beauvoir describes the affective nature

\footnotetext{
${ }^{179}$ Shiloh Whitney, "Byproductive Labour: A Feminist Theory of Affective Labour Beyond the ProductiveReproductive Distinction," in Philosophy and Social Criticism 44 no. 6 (2018): 638-639.

${ }^{180}$ For example, epistolary narratives include John Dos Passos' US A trilogy (1938) and Franz Kafka often employs embedded narratives. Beauvoir refers to both Dos Passos and Kafka as literary influences in both "My Experience as a Writer" and The Prime of Life.

181 In Memoirs of a Dutiful Daughter, The Prime of Life, America Day by Day, and "My Experience as a Writer" Beauvoir reflects on how this element of modern novels, including those by Virginia Wolfe, James Joyce, John Dos Passos, William Faulkner and Earnest Hemmingway, attracted her. She would often borrow English novels from a small library and documents in her autobiographies and interviews how she had enjoyed reading English novels since childhood (her childhood favourite being Louisa May Alcott's Little Women). For a succinct summary of this influence see Elizabeth Fallaize's introduction to "It's Shakespeare they don't like," "The Novel and the Theater," "An American Renaissance in France," and "New Heroes for Old," in "The Useless Mouths" and Other Literary Writings, ed. Margaret A. Simons \& Marybeth Timmerman (Urbana: University of Illinois Press), 94-96.
} 
of being-amongst-others, situating All Men Are Mortal in the larger phenomenological tradition as well as a larger literary tradition that capitalizes on embedded narratives.

What is the effect of Fosca's story? This final chapter argues that Regina's experience of Fosca's story simulates an existential coming-of-age. By listening to and learning from Fosca's story, Regina realizes that a meaningful life depends on her relationships with others. By the time Fosca completes his story, Regina has the knowledge Beauvoir deems necessary to live an ethical life, one that consists of a constant re-evaluation of, and participation in, meaningful projects with others. By finishing the novel with Regina's coming of age, Beauvoir highlights the broader narrative arc of her ethics. Like Regina, we now know how to live meaningful lives in community with others.

This chapter is split into three sections. The first section analyses the conventional reading of Regina. The second examines her character development in response to Fosca's story. The third articulates the uncanny nature of Regina's coming of age: due to the ambiguous nature of beingamongst-others, human experience is a life-long process of choice, adaptation, and re-evaluation. Just as we are being-amongst-others, we are perpetually coming of age.

4.1 Regina: that strident monster of vanity and egotism... ${ }^{182}$

In the scarce literature on All Men Are Mortal, scholars conventionally interpret Regina as an illustration of bad faith, narcissism, self-objectification, and obnoxiousness. For example, Kristina Arp argues that Regina relies on the gaze of others to exist. ${ }^{183}$ This means that Regina's sense of value is not derived from her own experience and participation in meaning making, but from what others decide is valuable. Regina adopts their values and conforms to their expectations, which is an act of bad faith. In “The Actress and Beauvoir," Joanna Morrison builds on Arp's argument to

182 Dûchene, “A Fabulous Freedom,” 27.

183 Arp, The Bonds of Freedom, 41. 
specify that Regina's bad faith is an illustration of narcissistic being-for-others. ${ }^{184}$ Both Arp and Morrison's analyses draw exclusively from the first section of All Men Are Mortal-the section Anne Dûchene's 1996 review encourages readers to muscle through in order to get to Fosca's story. ${ }^{185}$ This means they fail to take into account the effect of Fosca's story on the 'strident monster' that is Regina, characterizing her in terms of failed ethical action.

Both Arp and Morrison present Regina as the narcissist, a stock character developed in Beauvoir's The Second Sex. As we saw in the first chapter, stock characters illustrate particular attitudes but fail to simulate our experience over time because they are relatively static characters. Contrarily, treating Regina as a three-dimensional character situated in a fictitious world reveals the affective relationship between Regina and her situation over time. Therefore, this section argues that Regina is less like the narcissist of The Second Sex and more like the child of The Ethics of Ambiguity. By re-conceptualizing her as a character with the capacity to change, like the child, we lay the groundwork necessary for a close analysis of her ethical maturation in response to Fosca's story.

Morrison argues that Regina is a prototype of Beauvoir's narcissist. ${ }^{186}$ Our embodiment means we are both subjects to ourselves and objects to others, but the narcissist sacrifices their subjectivity in favour of objectivity. As a result of this self-objectification, the narcissist determines their selfworth based on how they are perceived. They behave as though they are nothing more than an object of desire to be consumed by others. ${ }^{187}$ Their lives consist of a performance behind which there is no subject, no unique perspective that can participate in meaning making. Therefore, by categorizing Regina as the narcissist, Morrison robs her of her capacity for meaning making. Since

${ }^{184}$ Joanna Morrison, “The Actress and Beauvoir," 3.

185 Dûchene, "A Fabulous Freedom," 27.

186 Morrison, "The Actress and Beauvoir," 3-4.

${ }^{187}$ Beauvoir, The Second Sex, 667-668. 
Beauvoir describes meaning making and freedom as mutually dependent, Morrison's reading also robs Regina of the ability to be free.

Morrison is not wrong to highlight Regina's narcissistic tendencies. Regina regularly thinks of herself as a consumable entity. When visiting her hometown, she recounts how as a child, she would "declaim the imprecations of Camilla beneath the shade of the weeping willow." ${ }^{88}$ This suggests that at an early age, she believed her value lay in her consumption by an audience. As an adult, Regina's performances reflect her in her audience's eyes, the organ through which she is metabolized. ${ }^{189}$ In “The Actress and Beauvoir," Morrison points out Regina's willingness to conform to the beauty standards of the film industry in order to be more digestible. Morrison argues that Regina willingly participates in self-objectification to land a job: "she declares herself willing to sleep with Dulac [a film producer] if necessary.” ${ }^{190}$ These descriptions of Regina's behaviour are all accurate; however, they highlight to specific points of time rather than summarize her being over time.

While Morrison and Arp accurately point out moments of narcissism, it is their interpretations, rather than Regina's behaviour, that are acts of bad faith. To present these moments as summaries of Regina's entire character, rather than moments in a larger narrative, deny Regina's capacity as a fictional human being to act her freedom and change over time. These interpretations ignore Beauvoir's own literary method, which depends on allowing characters their own fictional freedom. In "My Experience as a Writer," Beauvoir describes how our interactions with fictional characters should be analogous to our interactions with others. The fictional character should be treated as having the same range of emotions and motivations as the real-life people they simulate. ${ }^{191}$

188 Beauvoir, All Men Are Mortal, 63.

189 Beauvoir, All Men Are Mortal, 2.

190 Morrison, "The Actress and Beauvoir," 12.

${ }^{191}$ Beauvoir, "My Experience as a Writer," 289. 
Rather than interpret the characters of a novel as unchanging, we should lend them our sense of time and experience. ${ }^{192}$ When reading Regina, we should interpret her as a free individual like ourselves, rather than an unchanging stock character. By allowing her the same freedom we do others in the world, we interpret her in good faith.

Not only do interpretations of All Men Are Mortal that present Regina as a stock character overlook her capacity for change; they simplify the amount of freedom she has, at the start of the novel, to do so. In order to re-conceptualize Regina as a character capable of change, and therefore as inspiration for our own ethical maturation, it is necessary to take her situation into account. By situating Regina in the world, we see how her narcissistic tendencies are partially functions of survival. As an actress, Regina's livelihood depends, to a certain degree, on her ability to selfobjectify. We see these pressures play out in an exchange between Regina and her maid Annie before she hosts the film producer, Dulac, at her home.

"Do I look beautiful this evening?"

Annie examined her with a critical eye. "I like your hair better in plaits."

"I know," Regina said. "But Roger wants me to tone down all my distinctive features. They only appreciate obvious beauty."

"It's a shame," Annie said.

"Don't worry. As soon as I've made two or three films, I'll make them accept my real face." "Does Dulac seem interested in you?"

"It's never easy to attract that type." [...]

"Be sure not to make a scene," said Annie anxiously. "Don't drink too much and don't get impatient." "193

Regina's narcissism, her obsession with her own consumption, is determined by those who decide her professional success. In order to pay her bills, she must be consumable. While she fantasizes about being valued for her uniqueness, Regina believes it is only possible after playing by the rules. Regina does not decide to play by these rules alone. Annie polices her behaviour — 'do not make a scene,' 'don't get too drunk,' - re-enforcing the external limitations of her freedom. Annie

\footnotetext{
192 Beauvoir, “My Experience as a Writer," 294.
}

193 Beauvoir, All Men Are Mortal, 21. 
and Regina are complicit in Regina's self-objectification, on which each of their livelihoods depend. Both women are limited by rules they did not invent, which they are not yet in a position to critique. Therefore, to say Regina behaves in bad faith is to ignore the relationship she has with a world she entered without having made the rules and which is designed to keep her in the dark about the artificial nature of those rules.

We could argue that Regina does not have to understand her situation in order to enact her freedom; she could just quit. ${ }^{194}$ This position ignores the oppressive reality of some social structures. In "Beauvoir on the Ambiguity of Evil," Robin May Schott identifies two conceptions of freedom in Beauvoir's thought that help us clarify Regina's position in the novel's prologue. The first is ontological freedom: our innate capacity to say 'yes' or 'no' to something, regardless of the consequences. ${ }^{195}$ However, we sometimes find ourselves stuck between a rock and a hard place. In these situations, it is more productive to consider what Schott calls social freedom, which is circumstantial. There are some circumstances in which the world's structures inhibit our choice. ${ }^{196}$

This dual conception of freedom articulates Beauvoir's understanding of the tension between liberty and limitation. In The Prime of Life, Beauvoir writes that "no individual can lose [themselves] in the circumambient universe; though it supports [them], it also influences [their] behaviour.’197 Beauvoir therefore understands being-in-the-world to include a tension between freedom and influence, which Regina's experience simulates. While Regina always has the capacity to say yes or no to the demands of her profession, her ability to do so is influenced by her understanding (or lack thereof) of the social limitations of the world.

${ }^{194}$ In a desperate bit to shock her friends, Regina declares she is quitting the theater; however, this decision, rather than from a desire for emancipation, comes from a place of insecurity. Beauvoir, All Men Are Mortal, 74.

195 Schott, "Beauvoir on the Ambiguity of Evil," 230.

196 Schott, "Beauvoir on the Ambiguity of Evil," 233.

${ }^{197}$ Beauvoir, The Prime of Life, 470. 
Navigating the tension between ontological and social freedom is a skill developed with experience over time. By writing a prologue, Beauvoir establishes a 'pre-narrative' version of Regina: a girl who does not yet understand recognize her ability to challenge those structures through the process of meaning making with others. In the prologue, Regina is similar to the child, who enters a world whose rules were determined by those who existed before her. Regina lives "in an infantile world because, having been kept in a state of servitude and ignorance [...] can only submit to the law, the gods, the customs, and the truths created by males." ${ }^{198}$ Her realm of freedom is restricted by the meaning making of others who wish to profit off of her, who establish and maintain the structures of the world without her, and who capitalize on her continued ignorance. Conceptualizing Regina as the child rather than the narcissist unveils the structures at play that keep her in a state of ignorance, rather than a state of bad faith.

This ignorance does not last forever. As they gain experience, the child discovers that many elements of the world are not natural. They begin to question authority. ${ }^{199}$ Beauvoir calls this the crisis of adolescence [crise d'adolescence]. ${ }^{200}$ The adolescent discovers their agency and the agency of others. ${ }^{201}$ They develop from a happily irresponsible bystander into a moral participant in the world with the responsibility to make choices and engage in meaning making. To deny this responsibility is to act in bad faith. ${ }^{202}$ To act in bad faith therefore depends on experiencing a crisis of adolescence. If we re-conceptualize Regina as the child, we re-frame the narrative of All Men Are Mortal as a simulation of ethical maturation and its climax as a crisis of adolescence. We can only judge Regina

198 Beauvoir, The Ethics of Ambiguity, 39-41.

${ }^{199}$ Beauvoir, The Ethics of Ambiguity, 41.

200 Beauvoir, The Ethics of Ambiguity, 41. Original French: Beauvoir, Pour une morale de l'ambiguity. Kobo e-book edition. In English, we say 'teenage angst,' but 'crisis' implies an agency that angst does not. Teenage angst is a passive experience. We can wallow in angst in a way we cannot in crisis. There is an immediacy to crisis that alludes to agency, choice, and responsibility, all characteristics of Beauvoir's ethical actor.

${ }^{201}$ Beauvoir, The Ethics of Ambiguity, 42.

202 Beauvoir, The Ethics of Ambiguity, 41. 
after her crisis — after reading the entire novel. If we should not judge a book by its cover, why should we judge a character by the prologue?

\subsection{Regina’s Reactions}

This section argues that paying close attention to Regina's character development in response to Fosca's story reveals a process of ethical maturation. Her experience over the course of All Men Are Mortal simulates an existential coming of age that culminates in a crisis of adolescence. As Fosca tells his story to Regina, we see her transition from a state of naïve confidence, to uncertainty, denial, and finally acceptance of her ethical responsibilities amongst others.

\subsubsection{Regina’s Separation}

While chapter three argues that our mortality serves as a common foundation upon which we can get together, Beauvoir does not argue that just because we can get together that we naturally or spontaneously do. Unlike Fosca, whose immortality means he cannot get together with others on the basis of shared mortality, Regina is mortal. Theoretically, she is capable of building relationships with others through which she can enact her freedom and participate in meaning making. If Beauvoir argued that human beings are naturally sociable creatures who get together spontaneously, Regina would not exist. In her original question of how people, originally separate, get together, Beauvoir acknowledges that we can be as separate as we can be social. Regina's separation from others throughout All Men Are Mortals prologue is demonstrative of how, while our mortality provides a common foundation upon which we can build relationships, we do not necessarily have to build these relationships. We must choose to do so.

Regina conceptualizes herself as fundamentally different from others, despite her ontological sameness. She consistently feels isolated and misunderstood. For example, after spreading gossip about her co-star Florence, she thinks "as if malice was ever pure! As if one was unkind just for fun! 
They would never understand [...] They were easygoing and indifferent; there was none of this bitterness burning in their hearts. I'm not of their kind." ${ }^{203}$ In this reflection, Regina characterizes herself as malicious, bitter, and invested while others are easygoing and indifferent.

After learning of Fosca's immortality, Regina wanders the streets of Paris thinking, "there were so many men, so many women, who breathed the same sweetness of spring nights just as fervently and for whom the world no longer existed... I am neither myself, nor am I like them; yet they exist as much as I do." ${ }^{204}$ Here, she goes one step further. Not only is she fundamentally different from those around her but different from all of humanity, from all those who have come before her and from all those who will come after. While Regina recognizes their existence, it is one she cannot empathize with.

Regina's lack of empathy means she struggles to understand others' perspectives. Watching Florence and her partner Sanier dance together at a café, she thinks that "she was not made for these ready smiles, the tender chitchat and that simple, mutual human understanding. She pushed open the door and plunged into solitude." 205 Regina thinks herself incapable of understanding the perspectives of others like Sanier and Florence. Instead of trying, she turns her back in favour of solitude. Despite the simple fact that Regina is mortal, she denies her common situation and emphasizes her separation from others.

Unlike Fosca, who tries to build meaningful relationships despite his difference, Regina actively antagonizes those around her. For example, after a performance, Annie compliments the audience's enthusiastic applause. Regina replies that they applauded Florence as much as her, as though Florence's success diminishes her own. Reflecting on her reply, Regina thinks, "Florence

\footnotetext{
203 Beauvoir, All Men Are Mortal, 10.

204 Beauvoir, All Men Are Mortal, 54.

205 Beauvoir, All Men Are Mortal, 65.
} 
doesn't give a damn about me [...] so why should I bother about her?" ${ }^{206}$ Later, coming home from a rehearsal, she finds Annie and Fosca talking, laughing, and eating together. Jealously, she vents her feelings of inadequacy at Annie's expense. In response to Annie's story about how the two met, Regina says, “'that's her usual prattle. She has to reel it off to all my friends. Anyhow, it's not particularly remarkable story. Annie is a romantic, you shouldn't believe a word she says.' Tears welled up in Annie's eyes, but Regina pretended not to notice. 'I'm going to make you really cry,' she thought with satisfaction." ${ }^{207}$ Regina punishes Annie for her personability and Florence for her artistry. In both cases, Regina antagonizes Annie and Florence as competitors rather than engaging with them as comrades. Achieving significance requires Regina to distance herself from others; in the competition for significance, she is a lone operative.

Whereas Fosca's loneliness is an unexpected consequence of his immortality, Regina's is chosen. By conceptualizing herself as fundamentally different from others, Regina's justifies her separation and spiteful behaviour. Her self-conception does not, however, occlude the fact that she is mortal. This means that she has the capacity, if she so chooses, to engage with others. Upon her deathbed, Marianne tells Fosca, "Try to remain a man among [people] [...] There's no other salvation for you." ${ }^{208}$ While Fosca's difference makes such salvation impossible, it is possible for Regina. As she listens to Fosca's story, she discovers that separation will not inspire significance. To live amongst-others will be her salvation.

\subsubsection{Regina’s Maturation}

Regina comes to Fosca's story from her experience of chosen solitude. This attitude does not change in response to the first section of Fosca's story, which details his experience of mortality and his decision to become immortal. Fosca recounts to Regina how he gains power of the state of

\footnotetext{
206 Beauvoir, All Men Are Mortal, 2.

207 Beauvoir, All Men Are Mortal, 56.

208 Beauvoir, All Men Are Mortal, 331.
} 
Carmona and drinks the elixir of life. Over the next two hundred years, he builds Carmona's political and economic power. Despite his success, he outgrows Carmona. Eager to establish a universal empire, he joins the Holy Roman Emperor's court.

Despite two hundred years of trials and tribulations, Fosca sets out on a new adventure. Regina is impressed Fosca had the strength to do so. ${ }^{209}$ Before Fosca continues his story, Regina suggests they stretch their legs: "there's nothing to stop us taking this road, is there? [...] Your heart beats, and one foot follows the other. Roads go on forever." 210 The first section of Fosca's tale is hopeful. He leaves Carmona in search of more power and prosperity, certain he will find them. Regina's laughter and casual reference to eternity, 'roads go on forever,' indicate she does not yet realize the cost of forever. She is not yet critically engaged with Fosca's story.

Furthermore, Regina reacts sarcastically to the death of Fosca's wife Beatrice. When Fosca tells Regina he does not know what became of her, that she undoubtably died, Regina responds, "basically, all stories have a happy ending." 211 Regina’s sarcastic response to Beatrice’s death indicates she still values immortality. If death came for Beatrice in the end, then what is the point of telling her story? If an interesting and dynamic woman like Beatrice is forgotten in death, what hope does Regina have? Beatrice’s death confirms Regina's high opinion of immortality and the significance she expects it to provide.

Fosca continues, recounting his failure to establish a global empire. At this point in his narrative, Fosca perceives the world around him as vast and empty, a void to be filled with universal rationalism. ${ }^{212}$ Fosca wants to fill the void before him; however, not everyone shares his perspective. After talking with the Holy Roman Emperor Charles V, Fosca thinks, "he was not concerned with

209 Beauvoir, All Men Are Mortal, 170.

210 Beauvoir, All Men Are Mortal, 170.

211 Beauvoir, All Men Are Mortal, 170.

212 Beauvoir, All Men Are Mortal, 173. 
an earthly future that he would never see with his own eyes." ${ }^{213}$ Charles V does not have to plan for eternity like Fosca. Fosca's plans fail, causing him to conclude that it is impossible to improve our circumstances. ${ }^{214}$ Human beings are doomed to disease, division, and death.

In response to this depressing conclusion, Regina is overwhelmed. Fosca's story starts to take effect as she struggles to understand his condemnation of human life:

'Don't go on,' she said. 'there's no point. It will be the same story right to the very end. I know it.'

'The same story, and every day different,' said Fosca. 'You have to hear it all.' [...]

'Can you picture that sail disappearing over the horizon and me standing on the shore, watching it disappear?'

'Yes, I can,' She said. And it was true; now, she could.

'When I've finished my story, I shall watch you disappear down the road. You know very well that you will have to disappear.'

She buried her face in her hands. 'I don't know. I don't know anything anymore.'

'But I know. And as long as I can go on talking, I'll talk.'

'And after?' she asked.

'Let's not think about after. I'll speak and you listen. For the time being, we have no questions to ask each other.'

'Very well. Go on.'215

Regina's response in this passage is markedly different from the previous. Begging Fosca to cease and desist, she feels the effect of his story: "it was true; now" ${ }^{216}$ Regina can imagine Fosca's experience, see immortality from his perspective. This exhausts her. She no longer laughs easily; she is confused, indicating she is no longer confident in her understanding of the relationship between meaning and the human experience. Her horizons are widening, but she looks to the end of Fosca's story with dread, anticipating that this story will continue in an uncomfortable exposition of the human experience.

Fosca then recounts his relationship with the adventurer Carlier. As we know from the previous chapter, Fosca and Carlier's relationship ends with Carlier's suicide. Listening to this tragic

213 Beauvoir, All Men Are Mortal, 188.

214 Beauvoir, All Men Are Mortal, 239.

215 Beauvoir, All Men Are Mortal, 241-242.

216 Beauvoir, All Men Are Mortal, 242. My emphasis. 
story of friendship spoilt, Regina responds that it "had to end that way," 217 to which Fosca replies that it did not. Carlier had the choice. ${ }^{218}$ Regina stubbornly repeats that Carlier's life had to end with his suicide; however, she will not have the courage to do the same. ${ }^{219}$ Fosca asks whether she will need courage, after all, death will come with or without it. To this, she response, "You don't know what you are talking about.”220 Her confusion turns to denial. Though Carlier had a choice in the type of death he experienced, she insists he did not. Carlier's experience reflects Regina's: her freedom is likewise limited by circumstance not entirely of her making. By insisting on Carlier's agency despite his circumstantial restrictions, Fosca reminds Regina that she too has the capacity to enact change in her life. This foreshadows the point when she will have to take up her ethical responsibility and enact her freedom.

Regina is not confident in her ability to so do. She says, "I wanted to live." 221 By using the past tense, she suggests that she believed her previous behaviour, her separation, would facilitate a meaningful life. She wanted to live, but now recognizes she would have not. Fosca does not hear her confession, continuing with a morbid description of his own attempted suicide, but we do. We alone witness Regina's quiet confession. Though, as long as Fosca continues, she does not have to reckon with her new ethical obligations.

Fosca continues. He tells Regina about the meaninglessness he experiences in Enlightenment Paris. There Fosca is, perpetually abandoned by others, doomed to live in the sublimity of a barren wasteland: in his nightmares, "there are no more [people]. They are all dead. The earth is white. The moon is still in the sky and it lights up an earth that is completely white. [He's] alone."222 Fosca no

217 Beauvoir, All Men Are Mortal, 271.

218 Beauvoir, All Men Are Mortal, 271.

${ }^{219}$ Beauvoir, All Men Are Mortal, 272.

220 Beauvoir, All Men Are Mortal, 272.

221 Beauvoir, All Men Are Mortal, 272.

222 Beauvoir, All Men Are Mortal, 402. 
longer sees the world as it is, but what it will become: devoid of human life, an illuminated rock shining down on him like the spotlight under which Regina performs, emphasizing his isolation.

Despite his doomsday prophesizing, Regina calmly absorbs Fosca's description, contemplating the crockery on the café table they stopped at to have tea. She impartially reflects, "They're just like the bowls we had when I was a child." ${ }^{223}$ This does not mean anything to her, "the words had already lost their meaning. She no longer had a childhood, nor a future; for her too, there was no more light; no longer any colours or smells. What she would still feel was the sharp, burning sensation in her mouth, her throat. She drank avidly." ${ }^{224}$ There are four significant elements to this response that indicate Regina's development. First, she is not confused nor does react in denial. Fosca's experience of meaninglessness as a result of his immortality has taught her that separation will not facilitate a meaningful life. Secondly, the reference to her childhood invites us to compare her experience to that of a maturing child. So close to the end of Fosca's story, she reflects on how the things of her childhood are now meaningless to her. Like Beauvoir's conception of the developing child, Regina questions the meaning inherent in the things of her childhood and finds them lacking. Third, unlike her previous responses, she does not dread the end of Fosca's story. "Let's get it finished," 225 she says, bracing herself for an ending that comes along with her ethical responsibility. Finally, despite her recognition of meaninglessness, she feels a burning desire to drink, indicating a desire to continue her embodiment. Regina did not only want to live before; she wants to live now. Together, these elements indicate that she is maturing, inching towards her crisis of adolescence.

${ }^{223}$ Beauvoir, All Men Are Mortal, 335.

224 Beauvoir, All Men Are Mortal, 335-336.

225 Beauvoir, All Men Are Mortal, 335-336. 


\subsection{Regina's Crisis of Adolescence}

While Fosca is doomed to an eternity of isolation, Regina is not. By the end of Fosca's story, she will have to make a decision: will she continue to live a life of separation, or will she enter into meaningful relationships with others? By describing her responses, Beauvoir models the process of ethical maturation, which peaks with a crisis of adolescence, initiating us into the world of ethical action. Fosca's account of lonely meaninglessness triggers Regina's realization that this is only the beginning. As long as we are being-in-the-world, we are coming of age.

As demonstrated in the previous chapter, being-in-the-word is often an experience of anxiety or uncanniness. Regina's experience is similar to that Sigmund Freud describes in his essay "The Uncanny.” Freud argues uncanniness comes alongside the realization that something familiar is not how it seems. ${ }^{226}$ His analysis emphasizes the concept of 'home,' beginning with the German beimlichkeit, meaning familiar, comfortable, intimate, of the house or family. ${ }^{227}$ However, heimlichkeit commonly translates to 'secrecy.' This transition stems from an association between 'home' and 'behind closed doors,' safe from prying eyes. The home is an ambiguous space: it can be comfortable as well as secretive. Freud continues to demonstrate the connection between heimlich and unheimlich. The 'un' connotates weird, eerie, or fearsome, drawing from the connection between the domestic sphere, secrecy, and suspicion. Freud concludes that what is uncanny is what "ought to have remained... secret and hidden but has come to light." ${ }^{\prime 22}$ The uncanny describes how our homes_-our comfortable places in the world-become foreign to us. It reveals that things are not necessarily as they seem.

Freud's account of the relationship between home and uncanniness is a useful tool for interpreting Regina's experience in All Men Are Mortal because Beauvoir's conception of ethical

\footnotetext{
${ }^{226}$ Freud, "The Uncanny," 620.

227 Freud, "The Uncanny," 622.

${ }^{228}$ Freud quotes this from Schelling but does not specify the original source. Freud, “The Uncanny,” 623.
} 
maturation is tied to an adolescent's discovery that their world — their home-is not how it seems. As argued in the first section, Regina lives in ignorance of the arbitrary nature of structures of the world and of her role in sustaining and challenging them. Listening to Fosca's story reveals her responsibility to engage with others and enact her freedom, the benefit of which is a meaningful life. Regina's experience of Fosca's story is one of realizing that the human experience is not what she thought.

In The Ethics of Ambiguity, Beauvoir writes that during adolescence, the child realizes the world is not how they thought: permanent and god-given. The adolescent realizes that meaning is dynamic and that we are responsible for its maintenance. They are "going to be called upon to participate in their operation... [They] will have to choose and decide. It is comprehensible that it is hard for [them] to live this moment of [their] history, and this is doubtless the deepest reason for the crisis of adolescence; the individual must at last assume [their] subjectivity." 229 The crisis of adolescence is therefore an experience of realization, one that reveals our ethical responsibilities.

Beauvoir describes the crisis of adolescence as the moment when ethical behaviour becomes possible. Since meaning is not inherent, it is imperative to participate in meaning making. According to Beauvoir, meaning making is not just a latent talent we all share, but one that must be enacted to live a good life. Failure to do so "implies dishonesty [...] which is a positive fault." ${ }^{230}$ Thus, the crisis of adolescence can be summarized as a point of choice: to enact one's freedom or not. The point at which we assume our responsibility for meaning corresponds with our newfound capacity for ethical action.

Regina experiences her crisis of adolescence in her hometown, which she thought was eternal, peaceful, and unchanging. ${ }^{231}$ After listening to Fosca's story, she is left to reckon with a world that

\footnotetext{
${ }^{229}$ Beauvoir, The Ethics of Ambiguity, 41-42.

${ }^{230}$ Beauvoir, The Ethics of Ambiguity, 41.

231 Beauvoir, All Men Are Mortal, 61.
} 
does not look the same as it did before. As Fosca concludes his story, she "stared at the door, thinking, 'When he's finished, I'll have to walk through that door, and on the other side of it there will be something else." ${ }^{232}$ Her conception of the world has changed. Beyond the door to the inn is not the eternal provincial town of her childhood, but something different. While the road, fields, and church remain, Regina's understanding of the human experience has shifted.

Fosca does not stay to help Regina come to terms with this shift. His work is done. Silently, he leaves. Regina steps outside the door and wonders if there are any means of escape. There are not:

She held her hands tightly to her mouth, her head slumped forward. She was defeated. In horror, in terror, she accepted the metamorphosis: midge, foam, ant, until death. 'And it's only the beginning,' she thought. She stood motionless, as if it were possible to play tricks with time, prevent it from following its course. But her hands grew taut against her quivering lips. It was when the bells began to chime the hour that she let out the first scream. ${ }^{233}$

This, the very last passage of the novel, describes Regina's crisis of adolescence. Fosca's story reveals the uncanny nature of the human experience: nothing is as it seems because nothing is fixed. Regina imagines herself transformed into the insects Fosca equates to human life, accepting that for Fosca, whose freedom is impeded by his inability to enter into meaningful relationships, that is all she could ever be. Fosca was never free to add significance to her life. This reveals a responsibility Regina must take up. As a mortal woman, she can and must get together with others if she desires a meaningful life. Inexperienced in doing so, she fantasizes that time will stop and save her from this responsibility. She knows it will not; she thinks to herself — this is only the beginning. The striking of the clock confirms the continuation of Regina's life and with it, her ethical responsibilities.

Regina's scream vocalizes her frustration with existence, which Beauvoir describes as incessant evaluations, decisions, and failures. ${ }^{234}$ As described in the first chapter, the ambiguity of being-

232 Beauvoir, All Men Are Mortal, 401-402.

233 Beauvoir, All Men Are Mortal, 403.

234 Beauvoir, The Ethics of Ambiguity, 139. Anyone who has ever screamed into a pillow can empathize with Regina in this moment. 
amongst-others will cause failure and uncertainty. Regina's scream therefore viscerally describes ethical life; it summarizes in one powerful expression of rage what Beauvoir writes in The Ethics of Ambiguity, that "morality resides in the painfulness of an indefinite questioning." 235

This is no reason for Regina to neglect her ethical responsibility to enact her freedom. In order to cultivate a meaningful life, we must act with others, take chances, and therefore assume the risk of failure. ${ }^{236}$ Beauvoir writes that to imagine life without failure is to dream of death, and Regina does not "have the courage to die." ${ }^{237}$ Failure is the cost of a meaningful life, for meaning is coauthored with others; "this does not mean that one must consent to failure, but rather one must consent to struggle against it without respite."238 Beauvoir knows this struggle is difficult; her acknowledgement of its difficulty is born alongside Regina's screams.

\subsection{Conclusion}

While Fosca's experience demonstrates how our mortality serves as a common foundation upon which we can exercise our freedom and create meaning with others, Regina's demonstrates that we must choose to do so. Paying close attention to Regina's development reveals Beauvoir's conception of ethical maturation, an existential coming of age. We have learnt that being-amongstothers is the source of a meaningful life. If she still desires significance, Regina, previously separate, must get together with others despite the associated risks.

All Men Are Mortal concludes with Regina's crisis of adolescence. Nothing follows her screams. We leave Regina in her hometown, where we imagine she is free to take up her freedom or not to. Only now could we judge her behaviour as in good or bad faith; however, we are not given the opportunity. It is not only a stylistic choice to conclude the novel at its climax, but an ethical

235 Beauvoir, The Ethics of Ambiguity, 144.

${ }^{236}$ Beauvoir, The Ethics of Ambiguity, 154.

237 Beauvoir, The Ethics of Ambiguity, 170; Beauvoir, All Men Are Mortal, 402.

${ }^{238}$ Beauvoir, The Ethics of Ambiguity, 170. 
one. Beauvoir's conception of ethical action is to enact our freedom in ways that allow others to do the same. At the outset of this chapter, we saw how previous readings of Regina were done in bad faith because they violate this ethical imperative. By leaving Regina at the moment she must take up her freedom, Beauvoir and her readers facilitate the imaginary circumstances in which Regina could do so. None of her actions, from this point on, are determined by Beauvoir's pen or our interpretation. Like all of us, Regina's story remains unwritten, open to new possibilities she can coauthor with others, open to the possibility of failure, and learning from that failure in process of perpetual maturation, perpetual coming of age. We can only hope Regina would take up her freedom, since Beauvoir claims that "one does not exist without doing something." ${ }^{239}$ The real question is: what will you do?

239 Beauvoir, The Ethics of Ambiguity, 170. 


\section{Conclusion}

Philosophy has often seen itself as a way of transcending the merely human, of giving the human being a new and more godlike set of activities and attachments. The alternative I explore sees it as a way of speaking humanly and being human. That suggestion will appeal only to those who actually want to be human, who see human life as it is, with its surprises and connections, its pains and sudden joys, a story worth remembering. ${ }^{240}$

This thesis began with the above quotation; with Martha Nussbaum's proposal to incorporate literature into the philosophical study of ethics. Nussbaum argues that literature is a valuable tool for thinking about ethical action because it privileges particular human experience. Turning to literary writing for ethical guidance will, therefore, only appeal to those who value lived experience, who consider human life a story worth remembering. Is lived experience a legitimate means of communicating ethical imperatives? Does it reliably teach us about what it means to be in-the-world and amongst-others? Is human life a story worth remembering?

Based on its investigation into Simone de Beauvoir's The Ethics of Ambiguity and All Men Are Mortal, this thesis answers with a resounding yes. Over the course of four chapters, we have seen how Beauvoir's literary devices, imagery, dialogue, plot, and character development serve particular philosophical functions. We conclude that Beauvoir's literary devices allow her to present ambiguity and freedom as necessarily embodied phenomena that flesh out her ethics (metaphorically and literally). It is only by assuming our responsibility for meaning making with others than we can, despite the ambiguities of lived experience, build meaningful lives.

Beauvoir's literary devices demonstrate how meaning, freedom, and ambiguity are cogenerative and how a detailed description of each can propose an ethics rooted in the truth of human experience. The first chapter analyzed five literary devices that simulate being-in-the-world and being-amongst-others in The Ethics of Ambiguity. By using first person narration and the flesh and 
blood or bone metaphor, Beauvoir invites us to adopt her perspective as our own and to recognize that freedom and ambiguity are born of embodied experience. By using conversational prose and stock characters, Beauvoir populates her conception of being-in-the-world with others by simulating our experience of ambiguity in meaning-making. These devices demonstrate the intersubjective experience of meaning making and ambiguity; the existence of both depends on acting amongst others.

The second chapter introduced All Men Are Mortal as that which demonstrates the conditions necessary for acting amongst others and meaning making. Following political theorists who construct hypothetical simulations of the human experience, Beauvoir juxtaposes her conception of our mortality with its hypothetical opposite: immortality. The third chapter demonstrated the connections between our ontology, freedom, and meaning making. It demonstrated how 'all people are mortal' is more than the title of Beauvoir's novel: it is the primary premise of her ethics. By determining the outer limits of our freedom, mortality inspires anxiety while providing a foundation upon which we can get together to create meaning, alleviating that anxiety. A meaningful life is only possible in community with others. Beauvoir describes meaning and ambiguity as two sides of the same coin, both born as we enact our freedom. An ethical life is one that participates in meaning making despite the risk of failure precipitating ambiguity poses.

Beauvoir proposes this ethics because living a meaningful life amongst others is not something we necessarily, spontaneously, do. Chapter four demonstrated the role that choice and understanding play in becoming an ethical actor. The final chapter followed Regina on a journey of ethical maturation that culminated with a decision point: to act amongst others or not to. By ending her demonstration of ethical maturation at its climax, Beauvoir demonstrates her ethics in action. We now have the knowledge necessary to try (and fail and try again) to live ethical lives. By relinquishing her hold on Regina's story, and therefore her influence on our interpretations, 
Beauvoir adheres to her own imperative, enacting her freedom such that we are free to enact ours.

We might enact our freedom by building on this research. This conclusion outlines some of the thesis's contributions to political theory and Simone de Beauvoir studies. It also provides some prompts for further research that depend on interpretations of human experience, that story worth remembering.

\subsection{Political Theory}

Beauvoir asks why people get together and what the necessary conditions are to do so. The Ethics of Ambiguity and All Men Are Mortal demonstrate that for Beauvoir, the reason to get together and the means of getting together are synonymous: the reason to get together is to live meaningful lives and the means of getting together is meaning making. By enacting our freedom amongst others, we establish meaningful relationships, through which we enact our freedom. Beauvoir's texts describe a theory of community formation that depends on our choice to take responsibility for meaning making with others.

Beauvoir's theory of community formation suggests how we should live without prescribing specific actions. It is up to us to take Beauvoir's outline and flesh it out. Therefore, there is a balance between the individual and the community in her thought. Beauvoir does not privilege the individual over the community or vice versa; the individual depends on the community in which they live for meaning, ${ }^{241}$ while the community depends on the choices of individual actors to come into being. The individual and the community are mutually constitutive entities rather than being diametrically opposed. Beauvoir provides an alternative to theories that sacrifice the flourishing of the community to the individual's security (such as in Hobbes' commonwealth) or individual's will for the general (as in Rousseau's in body politic). By outlining a symbiotic connection between the individual and

\footnotetext{
241 Beauvoir, The Ethics of Ambiguity, 6.
} 
the community rather than a conflict of interest, Beauvoir suggests that being an individual and in community are equally valid human experiences and that one does not have to monopolize the other. Further research into the relationship between Beauvoir's devices and content could tease out this relationship to greater specificity.

Despite their symbiotic relationship, Beauvoir claims the individual precedes the community. ${ }^{242}$ Therefore, further research into the relationship between Beauvoir's literary devices and content could include investigations into Western individualism. For example, Fosca’s experience of the evolution of Western individualism mirrors Charles Taylor's accounts. When Fosca fails to establish a universal empire, he reflects on how his failure is the result of a selfunderstanding that posits ourselves as independent authorities rather than as members of a group. Fosca realizes that if Martin Luther is allowed to preach, he would lose an apparatus of control: "Through the mouths of priests, I could make God speak in whatever manner I wished. On the other hand, if each individual sought God in [their] own conscience, I knew very well that is would not be me who he would find there." ${ }^{243}$ Taylor similarly argues that Western individualism developed out of the Reformation. ${ }^{244}$ Taylor considers the evolution of a self-understanding grounded in individualism to be the grand narrative of modernity. ${ }^{245}$ However, since Taylor's narrative analyzes ideas rather than demonstrating action, it runs the risk of erasing the actions of individuals from that narrative.

By centering Fosca's experience in All Men Are Mortal, Beauvoir casts individual actors in the broader narrative of history. Beauvoir names those who disrupt Fosca's plans: the Duke of

242 Beauvoir, The Ethics of Ambiguity, 17.

243 Beauvoir, All Men Are Mortal, 192-193.

${ }^{244}$ Charles Taylor, Sources of the Self: The Making of The Modern Identity (Cambridge: Harvard University Press, 1989), 215; Charles Taylor, A Secular Age (Cambridge: Harvard University Press, 2007), 146.

245 Taylor, Sources of the Self, 305; A Secular Age, 146-158. 
Bourbon, the Pope, Martin Luther, and the Prince of Orange. ${ }^{246}$ While both Beauvoir and Taylor think that individuals make history, ${ }^{247}$ Beauvoir's narrative shines the spotlight on individual actors by simulating an embodied experience of history via these characters' actions and perspectives. By juxtaposing Fosca's belief in universalism with individuals' actions, Beauvoir suggests the 'impersonal' ambiguity of history comes down to the freedom of individual choice. Narrative therefore provides us an alternative form of theorizing about Western individualism that takes one's experience of individualism itself as its starting point.

Beauvoir's literary devices provide a unique perspective on individuals throughout history, but who are these individuals? Beauvoir's focus on the child in The Ethics of Ambiguity and on maturation in All Men Are Mortal includes the young. While disciplines like psychology, political economy, political science, social work, and sociology often consider the experiences of young people, the political theory cannon rarely does. By taking childhood and maturation seriously, Beauvoir legitimizes them as unique experiences of being-in-the-world-amongst-others. This calls us to remember and incorporate the perspectives of the 'naïve,' 'hormonal,' and 'immature,' when we theorize about community and provides opportunities for comparative work with those who do consider young people. Considering the experience of young people might reveal truths about the human experience we have long since forgotten.

\subsection{Simone de Beauvoir Studies and Existentialism}

This thesis also contributes to Simone de Beauvoir studies and existentialism. It expands our understanding of how specific literary devices invoke embodied experience and construct an ethical imperative. This situates The Ethics of Ambiguity and All Men Are Mortal in a broader phenomenological tradition alongside Heidegger's Being and Time. Unlike Being and Time, whose

\footnotetext{
246 Beauvoir, All Men Are Mortal, 206.

247 Taylor, A Secular Age, 156.
} 
primary task is to describing being-in-the-world, Beauvoir's literary devices allow her to describe being and prescribe action at the same time by accommodating multiple perspectives at once.

Beauvoir's unique contribution to existentialism is this ability to describe being and ethics at once. For example, by simulating embodied experience over time, Beauvoir fleshes out an existential ethics more substantially than Sartre can within the limits of his 1945 lecture, "Existentialism is a humanism.” When asked 'what do I do?', Sartre's responds 'You are free, so choose; in other words, invent. No general code of ethics can tell you what you out to do.”248 In comparison, Beauvoir's ethical imperative is slightly more detailed: enact our freedom in ways that allow others to enact theirs. Sartre and Beauvoir charge us with the same responsibility for meaning; however, Sartre's imperative holds our choice as its end while Beauvoir's holds the freedom of others. ${ }^{249}$ For Sartre, as long as we make choices, we are ethical actors. For Beauvoir, as long as our choices allow others to make theirs, we are ethical actors. Beauvoir's imperative is more attuned to living in community. Existentialism is not an individualistic program for either Sartre ${ }^{250}$ or Beauvoir; however, teasing out the mutually constitutive relationship between individuals and communitiesbetween our being and our ethical actions amongst others-distinguishes her contribution to existential ethics from Sartre's.

This does not preclude Sartre's ability to articulate an ethical imperative using similar means as Beauvoir. This thesis makes a methodological contribution to the study of existentialism by providing a model we can use to approach other literary existential texts like Sartre's novels. As is the case for Beauvoir's fiction, previous studies often focus on overarching philosophical themes in Sartre's literary works, ${ }^{251}$ neglecting the role specific literary devices have in simulating lived

248 Jean-Paul Sartre, "Existentialism is a Humanism," in Existentialism is a Humanism, ed. John Kulka, trans. Carol Macomber (New Haven \& London: Yale University Press, 2007), 33.

249 Beauvoir, The Ethics of Ambiguity, 23-24.

${ }^{250}$ Sartre, "Existentialism is a Humanism," 23-24.

251 See Gary Cox, Sartre and Fiction (London: Continuum International Publishing, 2009); “The Aesthetics of 
experience. By reading Sartre's novels using a combined approach of literary analysis and

phenomenological hermeneutics, we can establish equal grounds for comparing the content of Beauvoir and Sartre's ethics, not only their rhetorical strength. ${ }^{252}$

This research has implications for comparative research within Beauvoir's collective works as well. For example, many of Beauvoir's essays share literary devices with The Ethics of Ambiguity, such as the contemporaneous The Second Sex. Turning to The Second Sex would help explain Beauvoir's charges of internalized misogyny leveled by feminist scholars since the 1970s, allowing them to overlook her contributions to the field. ${ }^{253}$ Taking Beauvoir's phenomenological method and literary devices seriously provides an opportunity to interpret the women described in The Second Sex, like the narcissist, the woman in love, and the mystic, as attitudes that flesh and blood women may take at a specific point in time in response to their oppressed situation, rather than descriptions of continuous being-in-the-world.

This interpretation would follow Beauvoir's own introduction to part three of The Second Sex, which introduces these characters as self-justifying attitudes. A literary analysis of these characters as stock characters reveals the insidious nature of women's oppression: by manifesting these attitudes in response to their specific circumstances continuously over time, narcissists, women in love, and mystics perpetuate their oppression. They become self-policing, unchanging, and therefore nonthreatening characters. Furthermore, the misogyny of Beauvoir's observations reflects the patriarchal systems in which her subjects exist. Reading part three of The Second Sex simulates our experience of the dismissive, reductionist, and essentializing attitude patriarchy has towards women. Interpreting

Salvation in Sartre's Nausea," in The Enigma of Good and Evil: The Moral Sentiment in Literature (Dordrecht: Springer Netherlands, 2005).

252 This method might be a fruitful tool in terms of other existentialist authors like Albert Camus. For example, it might be a useful approach to his conception of the 'absurd' in comparison to Beauvoir's 'ambiguity.'

${ }^{253}$ Kate Kirkpatrick, "Past Her Prime? Simone de Beauvoir on Motherhood and Old Age,” in Sophia 53 (2014): 276; Sonia Kruks, "Gender and subjectivity: Simone de Beauvoir and contemporary feminism," in Signs 18, no. 1 (1992): 95. 
The Second Sex with a special mind to the role of stock characters, situation, and simulated experience might rescue Beauvoir from mere 'ancestor worship'254 and make her relevant to feminist discourse once again by demonstrating the connection between Beauvoir's feminism and the phenomenological tradition in which it is situated. Women's issues are philosophical issues.

This thesis not only provides a model for interpreting Beauvoir's other essays, but her novels as well. Regina's maturation in All Men Are Mortal provides a template for thinking about Beauvoir's other heroines. For example, Regina can serve as a foil to Françoise from Beauvoir's 1943 novel She Came to Stay, whose relationship struggles culminate in another woman, Xavière's, murder. Comparing Françoise's development with Regina's may reveal how different experiences and relationships result in divergent understandings of being-in-the-world.

While Fosca acts as a mentor to Regina, Françoise lacks a similar relationship. Perhaps this accounts for the divergence of the two women's actions. Both women begin their respective stories ignorant of the ethical implications of their relationships with others; however, Regina's freedom is won at no cost to another's. Comparatively, Françoise's is won at the cost of Xavière's. Perhaps Francoise's lack of guidance and isolation over the course of She Came to Stay accounts for her failed ethical action. Perhaps Françoise represents what Regina would be capable of without Fosca’s guidance. Either way, this thesis provides a model for thinking about other essays and novels from Beauvoir's moral period.

These suggestions for further studies are in no ways exhaustive. For example, the uncanny in All Men Are Mortal suggests further analysis of gothic imagery might be fruitful, like of the sublime and its implications for meaninglessness. Additionally, All Men Are Mortal, spanning multiple centuries, could be interpreted as a time-travel narrative. Since they follow individuals over the course of many, or extended, timelines, time-travel narratives provide an opportunity to think about

\footnotetext{
${ }^{254}$ Kruks, "Gender and subjectivity,” 95.
} 
the tension between individual agency and the contingent nature of history. Lastly, Beauvoir's literary theory provides opportunities to re-think the dichotomy between self and other insofar as the written word transcends_-or penetrates — the two. This is the beauty of literary works: due to their ambiguity of expression and the intersubjective nature of meaning making, interpretive possibilities are plentiful. This is good news for anyone interested in the Beauvoir specifically and in the intersection between philosophy and literature generally; opportunities for further research are hardly limited resources.

\subsection{Hybrid Modes of Expression}

This abundance of interpretive opportunities has its own complications and challenges; therefore, this thesis concludes with some remarks on the relationship between form and content and some questions relevant to any mode of written communication. For example, how do we navigate the tension between authorial intent and interpretive freedom? Beauvoir's ethics provides a guideline for navigating this tension. If ethical action is enacting our freedom in ways that allow others to do so too, then ethical reading leaves the writer their autonomy. Our interpretation of a literary scene, device, or trope is limited by the larger narrative in which the author embedded it. This means that our interpretations still rely on a vigorous and honest interpretation of the text as a whole. Likewise, writers must be mindful of their readers' interpretive power. Like Beauvoir, we must be comfortable in the ambiguity born alongside any means of human communication. This means writing with a variety of literary devices in order to set our interpreters up for success. If communicating the truth of the human experience is our goal, then we should embrace means of communication that cast the widest net.

This thesis argues that Beauvoir's literary devices present freedom and ambiguity as embodied phenomena, allowing her to articulate an ethics of ambiguity grounded in lived experience. By 
extension, it implicitly argues that the ideal form of theorizing about the human experience and ethical action is a hybrid form of expression that can hold multiple meanings at once. Philosophical purists might respond, 'does this not do violence to art insofar as literary writing is an aesthetic pursuit? Is it ethical to use literature in this way?' Their questions derail our pursuit of experiential truth in favour of an unresolvable debate over whether literary works are meant to be enjoyed or used - a debate that has taken up so much oxygen there is barely enough left to do either. The experience of writing this thesis demonstrated that enjoyment and use are not mutually exclusive categories. Of course, it is not literature's job to teach us how to be good people any more than it is music's job to teach us to be good dancers; however, paying special care to the relationship between form and content gives us practice in taking care of our materials and of each other. Above everything else-its arguments, contributions, and prompts for further research—this thesis is an act of love for the materials it explored. It is an act of careful use rather than consumption and abuse.

Despite the tension between use and abuse lying beneath the intersection of ethics and aesthetics, neither the 'philosophical purists' nor the 'literary ethicists' have a monopoly on art. To decide once and for all whether literary devices are valuable because they are aesthetically pleasing or because they serve philosophical functions is not our job. To decide anything once and for all is not our job, for the very least because doing so would put us all out of a job. Our job, as political philosophers, is to think about how to live good lives in community with others and to tell the truth of our experience in ways that reflect the ambiguity of that experience. This thesis demonstrates how literary devices constitute more than a pursuit of beauty and have a greater role than merely the handmaiden of philosophical discourse. They are contributing partners. In the case of Simone de Beauvoir's ethical project, and in political theory generally, hybrid forms of expression are invaluable contributors to conversations about the human experience-about the meaningful lives of those who live in community with others. These are stories worth remembering. 


\section{Bibliography}

"The Aesthetics of Salvation in Sartre's Nausea," in The Enigma of Good and Evil: The Moral Sentiment in Literature. Dordrecht: Springer Netherlands, 2005.

Andrew, Barbara S. "Beauvoir's Place in Philosophical Thought." In The Cambridge Companion to Simone de Beauvoir. Edited by Claudia Card. Cambridge: Cambridge University Press, 2003. 24 44.

Arendt, Hannah. The Human Condition. Chicago: University of Chicago Press, 1958.

Armstrong, Nancy. How Novels Think: The Limits of Individualism from 1719-1900. New York: Columbia University Press, 2005.

Arp, Kristina. The Bonds of Freedom: Simone de Beauvoir's Existentialist Ethics. Chicago: Open Court, 2001.

de Beauvoir, Simone. America day by day. Translated by Carol Cosman. London: University of California Press, 2000.

de Beauvoir, Simone. “An American Renaissance in France.” New York Times. 1947: 47-45.

de Beauvoir, Simone. All Men Are Mortal. London: Virago, 2003.

de Beauvoir, Simone. Cabiers de jeunesse: 1926-1930. Edited by Sylvie Le Bon de Beauvoir. Paris: Gallimard, 2008.

de Beauvoir, Simone. The Ethics of Ambiguity. Translated by Bernard Frechtman. New York: Open Road Integrated Media Inc., 2019.

de Beauvoir, Simone. "Existentialism and Popular Wisdom." Translated by Marybeth Timmermann. In Simone de Beauvoir: Philosophical Writings. Edited by Margaret A. Simons, Marybeth Timmerman \& Mary Beth Mader. Urbana: University of Illinois Press, 2004. 203-219.

de Beauvoir, Simone. "Introduction to an Ethics of Ambiguity." Translated by Marybeth Timmermann. In Simone de Beauvoir: Philosophical Writings. Edited by Margaret A. Simons, Marybeth Timmerman \& Mary Beth Mader. Urbana: University of Illinois Press, 2004. 289298.

de Beauvoir, Simone. "It's Shakespeare They Don't Like.” Translated by Marybeth Timmermann. In "The Useless Mouths" and Other Literary Essays. Edited by Margaret A. Simons \& Marybeth Timmerman. Urbana: University of Illinois Press, 2011. 98-101.

de Beauvoir, Simone. L’invitée. Paris: Gallimard, 1943. Kobe e-Book edition. 
de Beauvoir, Simone. "Literature and Metaphysics." Translated by Veronique Zaytzeff. In Simone de Beauvoir: Philosophical Writings. Edited by Margaret A. Simons, Marybeth Timmerman \& Mary Beth Mader. Urbana: University of Illinois Press, 2004. 261-277.

de Beauvoir, Simone. “Littérature et métaphysique.” In Les Temps Modernes 1, no. 7 (1946): 11531163.

de Beauvoir, Simone. The Mandarins. Translated by Leonard M. Friedman. London: The Collins Publishing Group, 1960.

de Beauvoir, Simone. Memoirs of a Dutiful Daughter. Translated by James Kirkup. London: Penguin Books, 1963.

de Beauvoir, Simone. "Moral Idealism and Political Realism." Translated by Anne Deing Cordero. In Simone de Beawvoir: Philosophical Writings. Edited by Margaret A. Simons, Marybeth Timmerman \& Mary Beth Mader. Urbana: University of Illinois Press, 2004. 175-193.

de Beauvoir, Simone. "My Experience as a Writer." Translated by Debbie Mann. In "The Useless Mouths" and Other Literary Essays. Edited by Margaret A. Simons \& Marybeth Timmerman. Urbana: University of Illinois Press, 2011. 218-301.

de Beauvoir, Simone. "New Heroes for Old." In "The Useless Mouths" and Other Literary Essays. Edited by Margaret A. Simons \& Marybeth Timmerman. Urbana: University of Illinois Press, 2011. 113-123.

de Beauvoir, Simone. "The Novel and The Theatre." Translated by Marybeth Timmerman. In "The Useless Mouths" and Other Literary Essays. Edited by Margaret A. Simons \& Marybeth Timmerman. Urbana: University of Illinois Press, 2011. 102-106.

de Beauvoir, Simone. Pour une morale de l'ambiguity. Paris: Gallimard, 1947. Kobo e-book edition.

de Beauvoir, Simone. "Preface to La Bâtard by Violette Leduc." Translated by Marybeth Timmerman. In "The Useless Mouths” and Other Literary Essays. Edited by Margaret A. Simons \& Marybeth Timmerman. Chicago: University of Illinois Press, 2011. 174-187.

de Beauvoir, Simone. The Prime of Life. Translated by Peter Green. New York: Penguin Books, 1962.

de Beauvoir, Simone. The Second Sex. Translated by Constance Borde and Sheila MalovanyChevallier. New York: Vintage, 2010.

de Beauvoir, Simone. She Came to Stay. London: Harper Press, 2006. Kobo eBook.

de Beauvoir, Simone. “A Story I Used to Tell Myself.” Translated by Veronique Zayteff \& Frederick Morrison. In "The Useless Mouths” and Other Literary Essays. Edited by Margaret A. Simons \& Marybeth Timmerman. Chicago: University of Illinois Press, 2011. 157-163.

de Beauvoir, Simone, Margaret A. Simons \& Jessica Benjamin. "Simone de Beauvoir: An interview." In Feminist Studies 5, no. 2 (1979): 330-345. 
de Beauvoir, Simone \& Madeleine Gobeil. "Simone de Beauvoir, an Interview: The Art of Fiction." Translated by Bernard Frechtman. In Women at Work 1: 47-67.

de Beauvoir, Simone. Tous les hommes sont mortels. Paris: Gallimard, 1946. Kobo e-Book edition.

de Beauvoir, Simone. "What Can Literature Do?” In "The Useless Mouths" and Other Literary Essays. Edited by Margaret A. Simons \& Marybeth Timmerman. Chicago: University of Illinois Press, 2011. 187-209.

de Beauvoir, Simone. "What is Existentialism?” Translated by Marybeth Timmermann. Simone de Beauvoir: Philosophical Writings. Edited by Margaret A. Simons, Marybeth Timmerman \& Mary Beth Mader. Urbana: University of Illinois Press, 2004. 324-326.

Bergoffen, Deborah. "Finitude and Justice: Simone de Beauvoir's All Men Are Mortal." In Philosophy Today 53, 2009: 116-121.

Bergoffen, Deborah. "Introduction to Pyrrhus and Cinéas." In Simone de Beauvoir: Philosophical Writings. Edited by Margaret A. Simons, Marybeth Timmerman and Mary Beth Mader (Urbina: University of Illinois Press, 2004. 79-87.

Berlin, Isaiah. "The Concept of Scientific History.” In Isaiab Berlin: The Proper Study of Mankind. Edited by Henry Hardy \& Roger Hausheer. London: Chatto \& Windus, 1997. 17-58.

Berlin, Isaiah. "Does Political Theory Still Exist?” In Isaiah Berlin: The Proper Study of Mankind. Edited by Henry Hardy \& Roger Hausheer. London: Chatto \& Windus, 1997. 50-90.

Berlin, Isaiah. "From Hope and Fear Set Free." In The Proper Study of Mankind. Edited by Henry Hardy \& Roger Hausheer. London: Chatto \& Windus, 1997. 91-118.

Berlin, Isaiah. "Historical Inevitability." In The Proper Study of Mankind. Edited by Henry Hardy \& Roger Hausheer. London: Chatto \& Windus, 1997. 119-190.

Berlin, Isaiah. "Two Concepts of Liberty." In The Proper Study of Mankind. London: Chatto \& Windus, 1997. 191-241.

Bogaerts, Jo. "Beauvoir's Lecture on the Metaphysical Novel and Its Contemporary Critiques." In Simone de Beauvoir Studies 29 (2014-2013): 20-32.

Brough, John B. "Art and Aesthetics." In Routledge Companion to Phenomenology. Edited by Sebastien Luft \& Søren Overgaard. London \& New York: Routledge, 2012. 287-296.

Brown, Wendy. “At the Edge.” In Political Theory 30, no. 4 (2002): 556-576.

Burke, Edmund. A Philosophical Inquiry into the Origin of Our Ideas of the Sublime and Beautiful. With an Introductory Discourse Concerning Taste, and Several Other Additions. Basil, 1792. Accessed via Gale Eighteenth Century Collections. 10 February 2021. 
Card, Claudia. "Introduction: Beauvoir and the Ambiguity of 'Ambiguity' in Ethics." In The Cambridge Companion to Simone de Beauvoir. Edited by Claudia Card. Cambridge: Cambridge University Press, 2003. 1-23.

Carmen, Taylor. “Forward.” In Phenomenology of Perception. Oxon: Routledge, 2014. vii-xvi.

Carrol, Noël. “The Creative Audience: Some Ways in Which Readers, Viewers, and/or Listeners Use Their Imaginations to Engage Fictional Artworks." In The Philosophy of Creativity. Edited by Elliot Samuel Paul \& Scott Berry Kaufman. Oxford: Oxford University Press, 2014. 62-81.

Cixous, Hélèn. "Fiction and Its Phantoms: A Reading of Freud's Das Unheimliche ('The Uncanny')." New Literary History 7, no. 3 (1976): 525-548.

Cox, Gary. Sartre and Fiction. London: Continuum International Publishing, 2009.

Currie, Gregory. "Creativity and the Insight That Literature Brings." In The Philosophy of Creativity. Edited by Elliot Samuel Paul \& Scott Berry Kaufman. Oxford: Oxford University Press, 2014. $39-61$.

Dûchene, Anne. “A Fabulous Freedom.” In Times Literary Supplement, no. 4842 (1996): 27.

Fallaize, Elizabeth. "Introduction to 'My Experience as a Writer'." In "The Useless Mouths" and Other Literary Writings. Edited by Margaret A. Simons \& Marybeth Timmerman. Urbana: University of Illinois Press, 2011. 277-281.

Fallaize, Elizabeth. "Introduction to "It's Shakespeare they don't like," "The Novel and the Theater," "An American Renaissance in France," and "New Heroes for Old."” In "The Useless Mouths" and Other Literary Writings. Edited by Margaret A. Simons \& Marybeth Timmerman. Urbana: University of Illinois Press. 91-97.

Fairfeild, Paul. The Politics of Individuality: Moral Selfhood in the Liberal Tradition. Toronto: University of Toronto Press, 2000.

Fell, Alison S. "Introduction to 'Preface to La Bâtarde by Violette Leduc'." In "The Useless Mouths" and Other Literary Writings. Edited by Margaret Simons \& Marybeth Timmerman. Urbana: University of Illinois Press, 2011. 167-173.

Freud, Sigmund. "The Uncanny." New Literary History 7, no. 3 (1976): 620-45.

Fullbrook, Edward. "She Came to Stay and Being and Nothingness." In The Philosophy of Simone de Beauvoir: Critical Essays. Edited by Margaret A. Simons. Bloomington \& Indianapolis: Indiana University Press, 2006. 42-64.

Gobeil, Madeleine \& Simone de Beauvoir. "Simone de Beauvoir: The Art of Fiction no. 35." Translated by Bernard Frechtman. In Women at Work, 1: 47-68.

Heidegger, Martin. Being and Time. Translated by Dennis J. Schmidt. Albany: State University of New York Press, 2010. 
Holveck, Eleanore. "The Blood of Others: A Novel Approach to The Ethics of Ambiguity." Hypatia 14, no. 4 (1999): 3-17.

Hughes, William. Historical Dictionary of Gothic Literature. Lanham: Scarecrow Press, 2012.

Killeen, Jarlath. History of the Gothic: Gothic Literature 1825-1914: Gothic Literature 1825-1914. Cardiff: University of Wales Press, 2009.

King Scheu, Ashley. "The Viability of the Philosophical Novel: The Case of Simone de Beauvoir's She Came to Stay." Hypatia 24, no. 4 (2012): 791-809.

Kirkpatrick, Kate. "Past Her Prime? Simone de Beauvoir on Motherhood and Old Age." Sophia 35, (2014): 275-287.

Kruks, Sonia. "Gender and subjectivity: Simone de Beauvoir and contemporary feminism.” In Signs 18, no. 1 (1992): 89-110.

Langer, Monica. "Beauvoir and Merleau-Ponty on Ambiguity." In The Cambridge Companion to Simone de Beauvoir. Edited by Claudia Card. Cambridge: Cambridge University Press, 2003. 87-106.

Luft, Sebastian \& Søren Overgaard. "Introduction.” In Routledge Companion to Phenomenology. London \& New York: Routledge, 2012. 1-14.

McKinnell, Liz. "The Ethics of Enchantment: The Role of Folk Takes and Fairy Tales in the Ethical Imagination." In Philosophy and Literature, 43 no. 1 (2019): 192-209.

Merleau-Ponty, Maurice. "Indirect Language and the Voices of Silence." In Signs. Translated by Richard McCleary. Illinois: Northwestern University Press, 1964. 39-83.

Merleau-Ponty, Maurice. "Man and Adversity.” In Signs. Translated by Richard McCleary. Illinois: Northwestern University Press, 1964. 224-243.

Merleau-Ponty, Maurice. "Man, The Hero.” In Sense and Non-Sense. Translated by Hubert L. Dreyfus \& Patricia Allen Dreyfuss. Illinois: Northwestern University Press, 1964. 182-187.

Merleau-Ponty, Maurice. "Metaphysics and the Novel." In Sense and Non-Sense. Translated by Hubert L. Dreyfus and Patricia Allen Dreyfus. Illinois: Northwestern University Press, 1964. 26-40.

Merleau-Ponty, Maurice. "Metaphysical In Man.” In Sense and Non-Sense. Translated by Hubert L. Dreyfus \& Patricia Allen Dreyfuss. Illinois: Northwestern University Press, 1964. 83-98.

Merleau-Ponty, Maurice. “On the Phenomenology of Language.” In Signs. Translated by Richard McCleary. Illinois: Northwestern University Press, 1964. 84-97.

Merleau-Ponty, Maurice. Phenomenology of Perception. Translated by Donald A. Landes. Oxon: Routledge, 2014. 
Merleau-Ponty, Maurice. "Reading Montaigne." In Sense and Non-Sense. Translated by Hubert L. Dreyfus and Patricia Allen Dreyfus. Illinois: Northwestern University Press, 1964. 198-210.

Merleau-Ponty, Maurice. "The Battle over Existentialism." In Sense and Nonsense. Translated by Hubert L. Dreyfus and Patricia Allen Dreyfus. Illinois: Northwestern University Press, 1964. 71-82.

Merleau-Ponty, Maurice. "The Philosopher and Sociology." In Signs. Translated by Richard McCleary. Illinois: Northwestern University Press, 1964. 98-113.

Mertens, Karl. "The Subject and the Self.” In Routledge Companion to Phenomenology. Edited by Sebastien Luft \& Søren Overgaard. London \& New York: Routledge, 2012. 168-179.

Moran, Dermot. "Edmund Husserl." In In Routledge Companion to Phenomenology. Edited by Sebastien Luft \& Søren Overgaard. London \& New York: Routledge, 2012. 28-39.

Morrison, Joanna. "The Actress and Beauvoir: Shining a Spotlight on Regina in All Men Are Mortal." In Outskirts: Feminism on the Edge 37 (2017): 1-21.

Mudde, Anna. "Beauvoir's Metaphysical Novel: Literature, Philosophy and Ambiguity”. In Socrates and Dionysus: Philosophy and Art in Dialouge. Edited by Ann Ward. Cambridge: Scholars Publishing, 2013. 192-203.

Mudde, Anna. “Living Experiments: Beauvoir, Freedom, and Science.” In PhaenEx 10 (2015): 57-75.

Murtagh, T. N. F. "Simone de Beauvoir, All Men Are Mortal and The Mandarins." In Man and World 7 , no. 2 (1974): 177-180.

Nanay, Bence. "An Experiential Account of Creativity." In The Philosophy of Creativity. Edited by Elliot Samuel Paul \& Scott Barry Kaufman. Oxford: Oxford University Press, 2014. 17-38.

Nussbaum, Martha. "The Discernment of Perception: An Aristotelian Conception of Private and Public Rationality." In Love's Knowledge: Essays on Literature and Philosophy. New York: Oxford University Press, 1990), 54-105.

Nussbaum, Martha. "Flawed Crystals: James' The Golden Bowl and Literature as Moral Philosophy." In Love's Knowledge: Essays on Literature and Philosophy and Literature. New York: Oxford University Press, 1990. 125-147.

Nussbaum, Martha. “"Finely Aware and Richly Responsible': Literature and the Moral Imagination." In Love's Knowledge: Essays on Philosophy and Literature. New York: Oxford University Press, 1990. 148-167.

Nussbaum, Martha. "Introduction.” In Love's Knowledge: Essays on Philosophy and Literature. New York: Oxford University Press, 1990. 3-53.

Nussbaum, Martha. "Perceptive Equilibrium: Literary Theory and Ethical Theory." In Love's Knowledge: Essays on Philosophy and Literature. New York: Oxford University Press, 1990. 168194. 
Nussbaum, Martha. Poetic Justice: The Literary Imagination and Public Life. Boston: Beacon Press, 1995.

Oatley, Keith, and David Olson. "Cues to the Imagination in Memoir, Science, and Fiction." In Review of General Psychology 14, no. 1 (2010): 56-64.

Oatley, Keith. Such Stuff as Dreams: The Psychology of Fiction. West Sussex: Wiley-Blackwell Publishing, 2011.

O’Neill, Patrick. "Narrative Structure." In The Routledge Encyclopedia of Narrative Theory. Edited by David Herman, Manfred Jahn, and Marie-Laure Ryan. London \& New York: Routledge, 2005. 368-370.

Ong, Yi-Ping. "Simone de Beauvoir's Theory of the Novel: The Opacity, Ambiguity, and Impartiality of Life." In Philosophy and Literature 39, no. 2 (2015): 379-405.

Parker, Emily Anne. "Singularity in Beauvoir's The Ethics of Ambiguity." In The Southern Journal of Philosophy 53 no. 1 (2015): 1-16.

Reynolds, Jack. "Existentialism." In Routledge Companion to Phenomenology. Edited by Sebastien Luft \& Søren Overgaard. London \& New York: Routledge, 2012. 485-95.

Richetti, John. The English Novel in History, 1700-1780. London \& New York: Routledge, 1998.

Rinofner-Kreidl, Sonja. "Moral Philosophy." In Routledge Companion to Phenomenology. Edited by Sebastien Luft \& Søren Overgaard. London \& New York: Routledge, 2012. 417-428.

Romdeh-Romluc, Komarine. "Maurice Merleau-Ponty." In Routledge Companion to Phenomenology. Edited by Sebastien Luft \& Søren Overgaard. London \& New York: Routledge, 2012. 103112.

Rubin, Susan. "Memory Troubles: Remembering the Occupation in Simone de Beauvoir's Les Mandarins." In French Politics, Culture and Society 28 no. 2, 2010: 4-17.

Sanos, Sandrine. Simone de Beauvoir: Creating a Feminist Existence in the World. Oxford: Oxford University Press, 2017.

Sartre, Jean-Paul. Being and Nothingness. Translated by Hazel E. Barnes. New York: Washington Square Press, 1992.

Sartre, Jean-Paul. Existentialism is a Humanism. Translated by Carol Macomber. New Haven \& London: Yale University Press, 2007.

Simons, Margaret A. "Bergon's Influence on Beauvoir's Philosophical Methodology." In "The Useless Mouths" and Other Literary Writings. Edited by Margaret A. Simons \& Marybeth Timmerman. Urbana: University of Illinois Press, 2011. 107-128.

Simons, Margaret A. "Introduction." In "The Useless Mouths" and Other Literary Writings. Edited by Margaret A. Simons \& Marybeth Timmerman. Urbana: University of Illinois Press, 2011. 1-8. 
Sirridge, Marry. "Philosophy in Beauvoir's Fiction." In The Cambridge Companion to Simone de Beauvoir. Edited by Claudia Card. Cambridge: Cambridge University Press, 2003. 129-148.

Shott, Robin May. "Beauvoir on the Ambiguity of Evil." In The Cambridge Companion to Simone de Beauvoir. Edited by Claudia Card. Cambridge: Cambridge University Press, 2003. 228-247.

Smith, Andrew. Gothic Literature. Edinburgh: Edinburgh University Press, 2013.

Stavro, Elain. Emancipatory Thinking: Simone de Beauvoir and Contemporary Political Thought. Montreal \& Kingston: McGill-Queen's University Press, 2018.

Stokes, Dustin. “The Role of Imagination in Creativity." In The Philosophy of Creativity. Edited by Elliot Samuel Paul \& Scott Barry Kaufman. Oxford: Oxford University Press, 2014. 157-84.

Taylor, Charles. A Secular Age. Cambridge: Harvard University Press, 2007.

Taylor, Charles. Sources of the Self. Cambridge: Harvard University Press, 1989.

Tidd, Ursula. "Introduction to A Story I Used to Tell Myself." In "The Useless Mouth" and Other Literary Writings. Edited by Margaret A. Simons \& Marybeth Timmerman. Urbana: University of Illinois Press, 2011. 153-56.

Toadvine, Ted. "The Chiasm.” In Routledge Companion to Phenomenology. Edited by Sebastien Luft \& Søren Overgaard. London \& New York: Routledge, 2012. 336-347.

Tolbert, Mary Ann. Perspectives on the Parables: An Approach to Multiple Interpretations. Philadelphia: Fortress Press, 1979.

Turner, M. The Literary Mind: The Origins of Thought and Language. New York: Oxford University Press, 1996.

Ward, Julie K. "Reciprocity and Friendship in Beauvoir's Thought." In The Philosophy of Simone de Beauvoir, edited by Margaret A. Simons. Bloomington \& Indianapolis: Indiana University Press, 2006. 146-162.

Weiss, Gail. "Simone de Beauvoir." In Routledge Companion to Phenomenology. Edited by Sebastien Luft \& Søren Overgaard. London \& New York: Routledge, 2012. 92-102.

Whitney, Shiloh. "Byproductive Labour: A Feminist Theory of Affective Labour Beyond the Productive-Reproductive Distinction." In Philosophy and Social Criticism 44, no. 6 (2018): 637660.

Vandevelde, Pol. “Narrative.” In Routledge Companion to Phenomenology. Edited by Sebastien Luft \& Søren Overgaard. London \& New York: Routledge, 2012. 360-369. 